\title{
Cenozoic to modern-day source to sink systems of Senegal: A record of provenance, transport, recycling and climate controls
}

DOI:

10.1016/j.jafrearsci.2021.104150

\section{Document Version}

Accepted author manuscript

Link to publication record in Manchester Research Explorer

Citation for published version (APA):

Mounteney, I., Casson, M., Ruston, J., Dethie, N., \& Redfern, J. (2021). Cenozoic to modern-day source to sink systems of Senegal: A record of provenance, transport, recycling and climate controls. Journal of African Earth Sciences, 178, [104150]. https://doi.org/10.1016/j.jafrearsci.2021.104150

Published in:

Journal of African Earth Sciences

\section{Citing this paper}

Please note that where the full-text provided on Manchester Research Explorer is the Author Accepted Manuscript or Proof version this may differ from the final Published version. If citing, it is advised that you check and use the publisher's definitive version.

\section{General rights}

Copyright and moral rights for the publications made accessible in the Research Explorer are retained by the authors and/or other copyright owners and it is a condition of accessing publications that users recognise and abide by the legal requirements associated with these rights.

\section{Takedown policy}

If you believe that this document breaches copyright please refer to the University of Manchester's Takedown Procedures [http://man.ac.uk/04Y6Bo] or contact uml.scholarlycommunications@manchester.ac.uk providing relevant details, so we can investigate your claim.

\section{OPEN ACCESS}




\section{Journal Pre-proof}

Discerning the provenance record of fresh detritus versus recycled sediment in Tertiary to modern-day source-to-sink systems of Senegal

Ian Mounteney, Max Casson, Jeremy Ruston, Ian Millar, Ndiaye Dethie, Jonathan Redfern

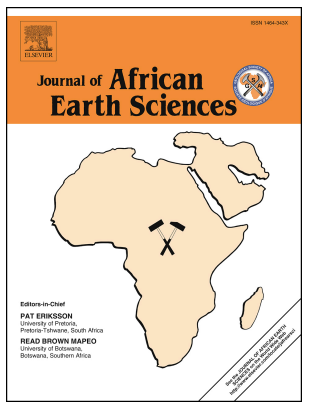

PII: S1464-343X(21)00051-0

DOI: https://doi.org/10.1016/j.jafrearsci.2021.104150

Reference: $\quad$ AES 104150

To appear in: Journal of African Earth Sciences

Received Date: 16 June 2020

Revised Date: 27 January 2021

Accepted Date: 11 February 2021

Please cite this article as: Mounteney, I., Casson, M., Ruston, J., Millar, I., Dethie, N., Redfern, J., Discerning the provenance record of fresh detritus versus recycled sediment in Tertiary to modernday source-to-sink systems of Senegal, Journal of African Earth Sciences, https://doi.org/10.1016/ j.jafrearsci.2021.104150.

This is a PDF file of an article that has undergone enhancements after acceptance, such as the addition of a cover page and metadata, and formatting for readability, but it is not yet the definitive version of record. This version will undergo additional copyediting, typesetting and review before it is published in its final form, but we are providing this version to give early visibility of the article. Please note that, during the production process, errors may be discovered which could affect the content, and all legal disclaimers that apply to the journal pertain.

(C) 2021 Published by Elsevier Ltd. 
1 Cenozoic to modern-day source to sink systems of Senegal: a record of

2 provenance, transport, recycling and climate controls

3 Ian Mounteney ${ }^{1,2}$, Max Casson $^{1,3}$; Jeremy Rushton ${ }^{2}$; Ian Millar ${ }^{4}$; Ndiaye Dethie ${ }^{5}$ and Jonathan

4 Redfern $^{1}$

$5{ }^{1}$ North Africa Research Group (NARG), Department of Earth and Environmental Sciences,

6 The University of Manchester, Williamson Building, Oxford Road, Manchester, M13 9PL, UK.

$7{ }^{2}$ Geochronology and Tracers Facility, British Geological Survey, Keyworth, Nottingham, $8 \quad$ NG12 5GG, UK.

$9{ }^{3}$ Equinor ASA, Forus Vest, Svanholmen 8, 4313 Sandnes, Norway.

$10{ }^{4}$ National Isotope Geoscience Laboratory, Kingsley Dunham Centre, Keyworth, Nottingham, 11 NG12 5GG, UK.

$12{ }^{5}$ University Cheikh Anta Diop de Dakar (UCAD) Cheikh Anta DIOP University of Dakar, Bp 135005 Dakar-Fann.

14 Corresponding author: iaian1@bgs.ac.uk

15 ORCiDs: IM (0000-0002-0295-9552); MC (0000-0003-4241-3447); JR (0000-0002-0536-

16 1492); JR (0000-0001-5931-7537); IM (0000-0002-9117-7025); ND (0000-0002-3848-7075)

17 Keywords

18 Provenance, Heavy mineral, Senegal, Africa, West African Craton, River, Quaternary,

19 Sediment recycling 
Abstract

21 This study presents an integrated mineralogical assessment for the provenance of

22 sediments derived from modern-day rivers and Cenozoic deposits in Senegal and Gambia.

23 Two distinct populations are identified from discrimination of the heavy mineral

24 assemblages; the Senegal River sediment, sourced from the West African craton and

25 Mauritanides and Meso-Cenozoic sediment sourced from the onshore Senegal basin,

26 demonstrating prevalent recycling of Senegal basin sediments by the Ferlo, Saloum, Gambia

27 and Casamance Rivers throughout the Quaternary.

28 The Senegal River records the occurrence of amphibole, epidote, garnet and pyroxene,

29 which indicates denudation of Neo to Paleo-Proterozoic granites, low-medium grade meta-

30 sediments and a skarn-type lithology. Meso-Cenozoic recycled sediments within the

31 onshore Senegal basin exhibit a heavy mineral component which has been modified through

32 the chemical-weathering and diagenesis of less-stable amphibole, pyroxene and garnet.

$33 \mathrm{U} / \mathrm{Pb}$ dating of zircons from the Casamance and Gambia provinces indicates that, at least in

34 part, the Mesozoic sediments of the onshore Senegal basin may have been ultimately

35 derived from the Leo-Man Shield.

36 Kaolin occurrence is associated with tropical weathering of laterites. The occurrence of

37 terrigenous-smectite sourced from high altitude regions of the Mauritanides and West

38 African Craton is interpreted to have formed under hyper-arid conditions prior to erosion

39 and transportation, during the African humid periods of the Holocene.

40 This integrated mineralogical study of modern-day and Cenozoic sediments has established

41 prevalent recycling of Senegal basin-sediments by the Ferlo, Saloum, Gambia and

42 Casamance Rivers and continued erosion and recycling of hinterland-sediments via the 
modern-day Senegal River. This identification of two distinct provenance groups and the strong climatic signal provides the important framework for future studies assessing the source to sink systems during the Meso-Cenozoic.

Introduction

Modern-day drainage of Senegal and Gambia is via four major river systems: The

Casamance, Gambia, Saloum and Senegal rivers (Fig. 1). These have drainage catchments in Mauritania, Senegal, Gambia, Guinea Bissau, Guinea and Mali. Feeder tributaries to the Senegal River includes the Ferlo River (central Senegal), Falémé, Bakoye and Bafing rivers (Guinea), Baoule (Mali) and the Kolinbine, Karakoro and Gorgol rivers (Mauritania). During their existence, these river systems may have eroded the Mauritanide orogenic belt, the West African Craton (WAC), the Leo-Man Shield, the Kédougou-Kéniéba Inlier (KKI) sediments of the Hodh, Taoudeni, Youkounkoun, Bove and Senegal-Mauritania Basins (Villeneuve et al., 2015).

Recently there has been renewed interest in the MSGBC (Mauritania-Senegal-GuineaBissau-Guinea-Conakry) basin due to the discovery of significant volumes of hydrocarbons offshore, most recently the FAN-1 and SNE-1 discoveries (Hathon, 2018). Extending exploration away from these discoveries will in-part rely on an improved understanding the controls on provenance and sediment supply to the NWAAM (North-West African Atlantic

61 Margin). In this study, we present an integrated mineralogical assessment of modern-day river sediments from the four major river systems of Senegal and Gambia, augmented with selected samples of Cenozoic sandstones. The results allow a developing understanding of 
the modern-day source-to-sink systems of Senegal, and this research presents the first published provenance study of the onshore Senegal basin.

Heavy mineral studies are frequently used to assess the stratigraphic and spatial variations of provenance over a region (Mounteney et al., 2017; Farrant et al., 2018; Fossum et al., 2019; Garzanti \& Ando, 2019). The results from this project can also be used as a control to understand paleo-river drainage of NW Africa and further refine models for sand delivery into the onshore and offshore basins.

\section{Regional Setting}

73 River geometry

74 The Senegal River (Fig 1) is the longest of the four river systems, with a river-length of $c a$. $1800 \mathrm{~km}$ (Kattan et al., 1987), and a total catchment of ca. 328,825 km² (Stanzel et al., 2018). The principle section of the River Senegal, between Bakal and St Louis (ca. 784 km; Shahin, 2002), is known as the Middle Senegal Valley (MSV; Coutros, 2018). Headwaters of the Senegal originate from the Falémé, Bakoye and Bafing rivers (Guinea), propagating in a north-westerly direction and intersecting with the Baoule (Mali), Kolinbine, Karakoro and Gorgol rivers in Mauritania. As the Senegal River passes through Northern Senegal, it shifts to a westerly direction following the Senegal-Mauritania border. The Ferlo River feeds into the Senegal River, at the junction of Lake de Guiers, before terminating at St Louis (Isupova \& Mikhailov, 2008). Prior to the construction of the Diama Dam in 1986, sediment run-off from the Senegal River averaged ca. $0.006 \mathrm{~km}^{3} / \mathrm{yr}$, this was reduced to $c a .0 .004 \mathrm{~km}^{3} / \mathrm{yr}$ after its construction (Isupova \& Mikhailov, 2008). The Gambia River is the second largest river in Senegal/Gambia spanning ca. 1,120 km from the Fouta Djallon plateau in Northern

87 Guinea, moving westwards through Senegal and The Gambia, exiting into the Atlantic Ocean 
88 at Banjul (Simier et al., 2006) with a total catchment of $41,888 \mathrm{~km}^{2}$ (Stanzel et al., 2018). The

89 Casamance River is a comparably smaller system, at $350 \mathrm{~km}$ in length. Its drainage

90 catchment is $13,850 \mathrm{~km}^{2}$ which is restricted to the Quaternary deposits of Southern Senegal

91 (Debenay et al., 1994). The Saloum is the smallest of the four rivers, at a mere ca. $250 \mathrm{~km}$ in

92 length (Faye et al., 2004), with the smallest catchment of ca. $8000 \mathrm{~km}^{2}$ (Pages \& Citeau, 93 1990).

94 River geometry is principally governed by local factors, such as relative stream size, valley

95 slope, sediment charge and relative settling size of the sediment (Shahjahan, 1970)

96 however, in a broader context, regional physiography and changes in climate can have a far

97 greater effect on river-systems (Grimaud et al., 2018; Isupova \& Mikhailov, 2008). Extreme

98 changes in climate can produce contrasting effects in fluvial systems with cessation of rivers

99 in hyper-arid conditions and flooded high-energy systems during more humid periods. 


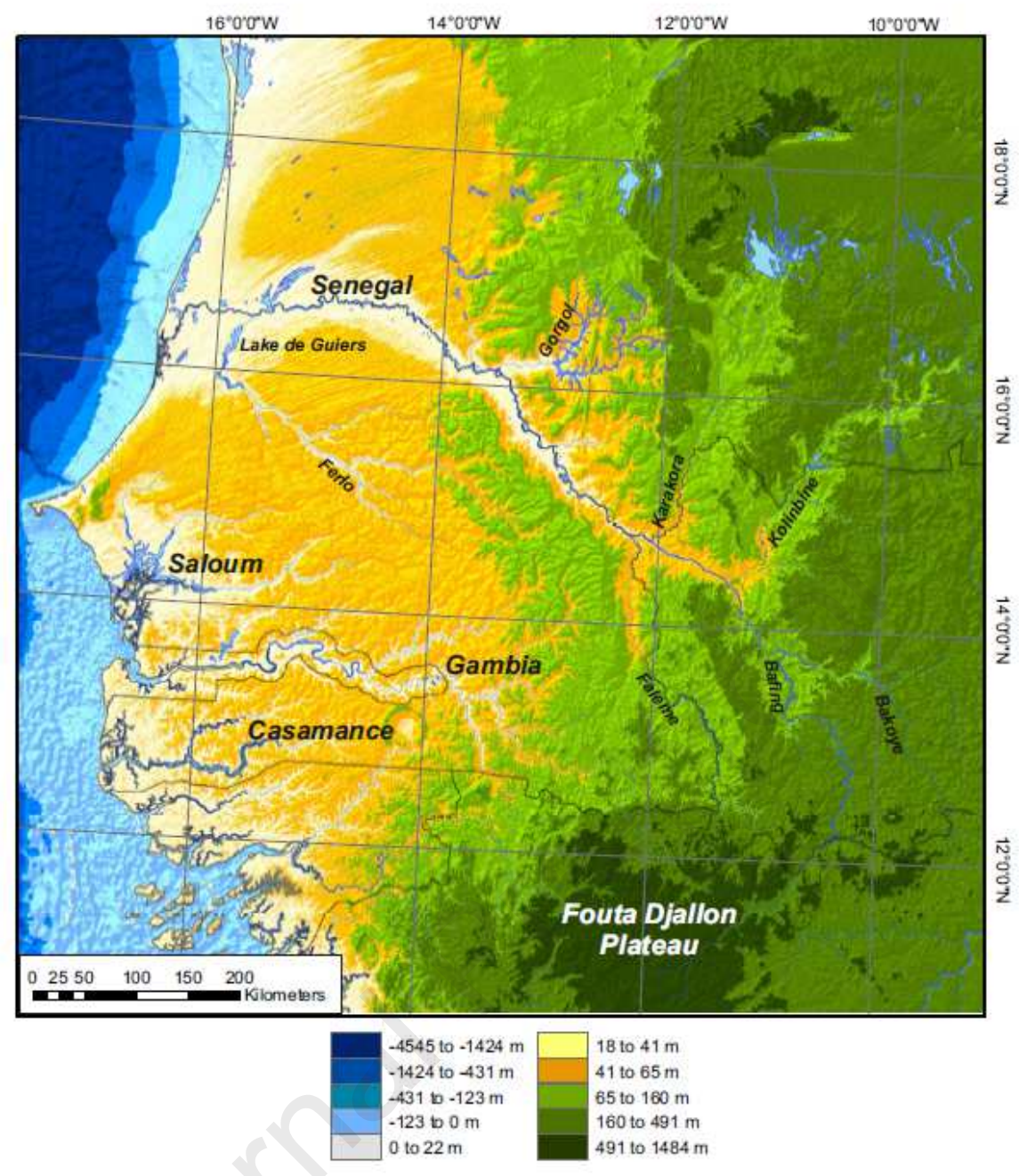

Figure 1 Digital elevation map (DEM) of Senegal and the major rivers (Senegal, Saloum, Gambia and Casamance) including

102 feeder tributaries from neighbouring countries. DEM model produced from data by the General Bathymetric Chart of the 103 Oceans (GEBCO; Becker et al., 2009). 


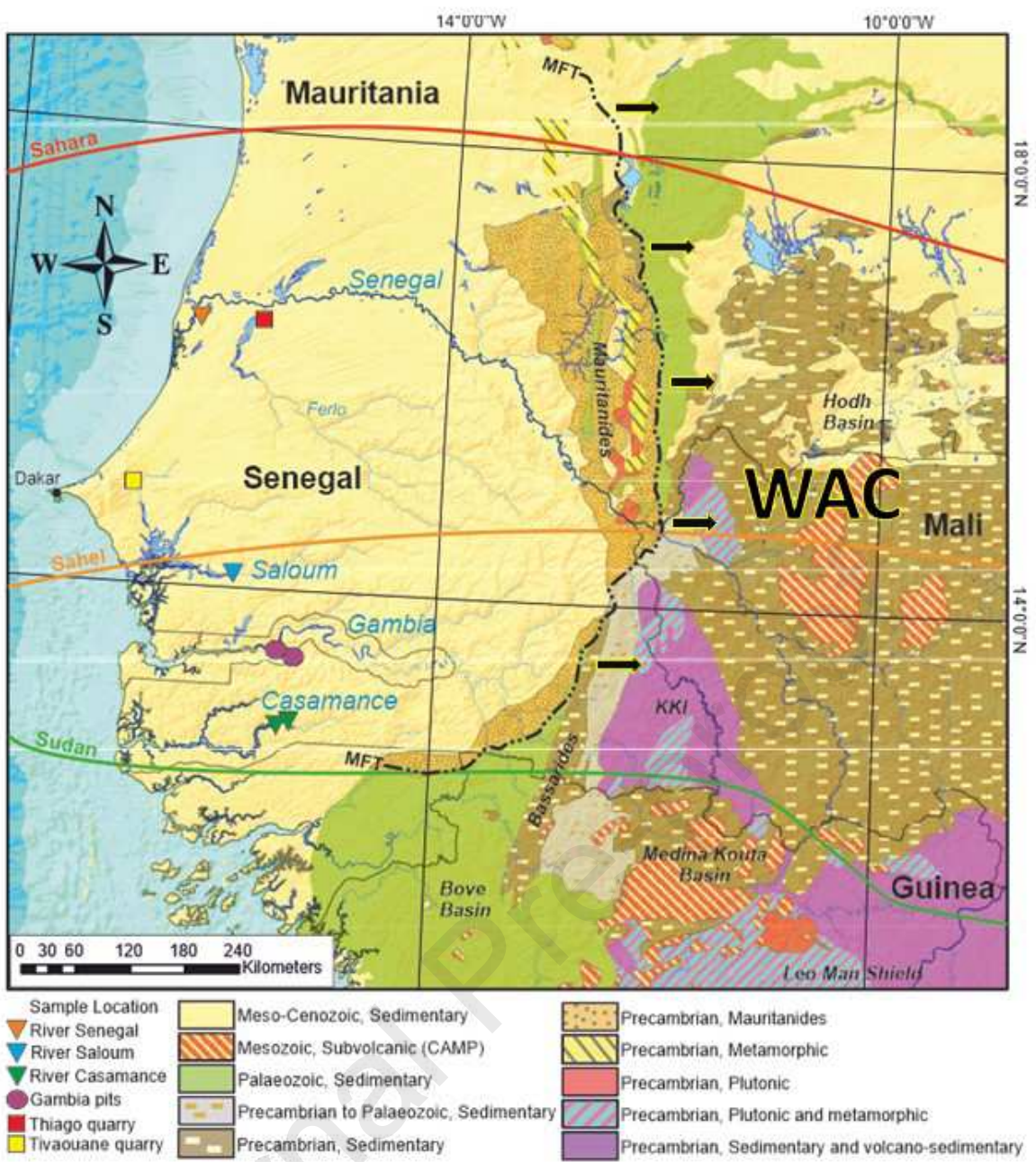

Figure 2 Geological map of NW Africa, location of sediments collected for this study and North-African Sahel, Saharan and Sudan climate zones. KKI-Kédougou-Kéniéba Inlier, MFT-Mauritanide front thrust, WAC-West African Craton. Compiled from Bellion and Crevola, 1991; Davison, 2005 and GEM, 2020.

109 Understanding the evolution of the Senegalese river systems through time is complex, with several factors governing their development. Mesozoic continental-margin tectonics

111 resulted in the formation of a series of sub-basins along the drainage pathway, with faulting,

112 rifting and development of topographic swells (Burke, 1976; Guiraud et al., 2005; Mourlot et

113 al., 2018; Ndiaye et al., 2016b; Uchupi, 1989). In the southern region of Senegal, a series of

114 sub- basins are divided by the Casamance failed rift-arm, where the Gambia River now resides (Burke, 1976). The emplacement of the Dome de Guiers in Northern Senegal during the Maastrichtian (Trenous \& Michel, 1971) established a dissymmetric graben-like 
structure, controlling the location of Lake de Guiers. This coincided with a series of

118 orthogonal faults, controlling the geometry of the River Ferlo.

119 Climate

120 During the Quaternary, North Africa experienced dramatic changes in climate, hydrology

121 and vegetation. The last glacial maximum of the Pleistocene (20-12.5 ka bp; Coutros, 2019)

122 affected global climate and sea-level; in North Africa this resulted in significant shifts to the

123 position of the intertropical convergence zone (ITCZ; Nicholson, 2017; Adam et al., 2019).

124 During the latter stages of this glacial period, sea-level was at least $100 \mathrm{~m}$ lower compared

125 to present-day levels (Diester-Haass, 1975). Precipitation in the Sahel region (Fig 2) was

126 reduced by $10-15 \%$ compared to modern levels, shifting the ITCZ southward by $2^{\circ}$ (Coutros

127 2019). This resulted in Senegal's climate entering into a period of hyper-aridity which

128 substantially reduced plant cover, creating an albedo-associated positive feedback loop,

129 exacerbating local aridity (Coutros, 2019; Ehrmann et al., 2017). During this hyper-arid 130 phase, the rivers south of $17^{\circ} \mathrm{N}$ (Mauritania) are believed to have ceased flowing, entering a

131 stage of stagnation (van Zinderen-Bakker \& Maley, 1977; Diester-Haass, 1975; Michel,

132 1973). A significant exception to the cessation of fluvial activity within the Sahel region is

133 the River Falémé in eastern Senegal, which may have been continually flowing due to its

134 headwaters being located further south in the Guinean Highlands (Coutros, 2019).

135 The ensuing Holocene interglacial period (11,700 years BP) ushered in the AHP (African 136 Humid Period) causing a sharp drop in temperature, $5-7^{\circ} \mathrm{C}$ cooler than in the Pleistocene 137 hyper-arid period; resulting in the northward expansion of the ITCZ to at least $12^{\circ} \mathrm{N}$ 138 (Coutros, 2019). Dramatic increases in precipitation of the WAM (West African Monsoon) 139 led to the reactivation of river-systems within the Sahel region of NW Africa. This increase in 140 renewed precipitation also resulted in the development of many lakes within the Sahel and 
tropic zones. A consequence of this increased precipitation was the development of the

142 largest pluvial lake in the world at this time; the Mega-Chad lake, covering an area of

$143361,000 \mathrm{~km}^{2}$, with a depth of up to $160 \mathrm{~m}$ (Armitage et al., 2015). On the north-western

144 edge of the Adrar region of Mauritania, the Chemchane sabkha (lat $21^{\circ} \mathrm{N}$, long $12^{\circ} \mathrm{W}$,

145 elevation $256 \mathrm{~m}$ ), is a NE-SW-orientated depression. This sabkha was transformed into a

146 lacustrine environment 8.3 to $6.5 \mathrm{ka}$ bp due to WAM precipitation during the AHP (Lézine et

147 al., 1990). Following a comparatively short period of hyper-aridity 7.8-6.7 ka, the Sahel

148 region of Africa returned to a second AHP peaking at 6.7 and $5 \mathrm{ka} b p$, at which time

149 Holocene sea-level had returned to a nominal -3 m below-present (Miller et al., 2005).

150 Basin morphology

151 The MSGBC Basin is the largest continental margin basin along the NWAAM. Senegal contains approximately half of the onshore portion of the MSGBC Basin, a total area of 340,000 km² (Davison, 2005; Ndiaye et al., 2016; Mourlot et al., 2018; Ritz \& Bellion, 1988) extending along a 1400 km segment of the NWAAM (Ritz \& Bellion, 1988; Brownfield, 2003; Brownfield, 2016). The basin is an "Atlantic-type" passive margin, with a prograding wedge of sediment that develops a broad shelf, which is in part exposed and extends offshore to form a steep shelf margin and slope, ultimately thinning onto oceanic crust. Central and western Senegal has an extremely low average elevation of $<65 \mathrm{~m}$ above sea-level, with some floodplains $<41 \mathrm{~m}$ below sea-level (Fig 1). There are a limited number of topographic

160 highs, which include: the Cap Vert Peninsula (Ndiaye \& Ngom, 2014; Hansen, 2008), Leona

161 Dome (Hansen, 2008; Ritz \& Bellion, 1994) and the Dome de Guiers (Trenous \& Michel, 162 1971).

163 The clastic infill predominantly consists of Meso-Cenozoic strata, thickening from east to 164 west, where it reaches a maximum thickness of $>10,000 \mathrm{~m}$ along the western Atlantic coast 
165 (Ndiaye et al., 2016b). These sediments overly pre-rift Palaeozoic strata of the Bove Basin

166 (Davison, 2005) and/or Precambrian basement (Davison, 2005; Guiraud et al., 2005;

167 Villeneuve et al., 2015).

168 Basin Evolution

169 Pre-Central Atlantic rifting and the establishment of the basin began during the Late

170 Palaeozoic fragmentation of the Gondwana supercontinent (Binks, 1992). During the

171 Permian/Triassic a large-scale network of rifts were established along the NWAAM, with

172 continued extension resulting in the final separation of Gondwana during the Early

173 Cretaceous, manifested by the complete separation of South America and Africa (Lehner,

174 1977; Storetvedt, 1985; Uchupi, 1989; Labails et al., 2010). The basin can be divided into

175 three regional blocks: the Toundou Block (Northern); Cayar, Dakar, and Gambia blocks

176 (Central); and the Casamance (Southern) (Gladimi, 1977), potentially controlling paleo-

177 drainage.

178 The Senegalese segment of the basin is fringed by the Mauritanides; a ca. $1500 \mathrm{~km}$ long 179 orogenic belt (Villeneuve et al., 2015; Villeneuve, 2008; Gueye et al., 2007), which formed as 180 an accreted terrain along the western margin of the WAC (Fig 2) in the Carboniferous (Page, 181 1988; Ponsard et al., 1988).

182 The section of the Mauritanides fringing the MSGBC basin can be further subdivided into the

183 Hercynian Belt to the North and the Bassaride Belt to the South, separated at $14^{\circ} \mathrm{N}$ latitude.

184 The Bassaride Belt is associated with the first Pan-African II tectonic event occurring 660-650

185 Ma with the northern segment of the Mauritanide belt associated with the Hercynian orogeny, 370-290 Ma (Villeneuve, 2008). Palaeozoic basins surround the eastern flank of the 
To the east of the Mauritanides is the West African Craton (WAC), this comprises two

Archean Shields: the Reguibat to the North, and the Leo-Man to the South (Villeneuve et al., 2015; Villeneuve, 2008; Gueye et al., 2007).

\section{Materials and Methods}

193

194

195

196

197

Heavy Minerals in sandstones

Heavy minerals are defined as minerals with a density of greater than $2.9 \mathrm{~g} / \mathrm{cm}^{3}$ and are typically found as accessory components $(<1 \%)$ in most sandstones (Morton \& Hallsworth, 1994). Their occurrence is principally due to their inherent "relative" resistance to weathering, erosion and diagenesis. Identification and analysis of this heavy mineral fraction can be diagnostic of specific geological source terrains/lithologies. Variations in the heavy mineral assemblage (stratigraphically and spatially) over a region can infer shifts in sediment provenance and potential mixing of sediments from multiple sources. Care must be taken when attempting to interpret provenance indicators; as processes during the sedimentary rock-cycle can modify the preserved heavy mineral signature. These processes can include initial weathering of the source rock, mechanical abrasion during transportation, hydraulic sorting of grains based on grain size and density during both transportation and deposition, selective dissolution during burial diagenesis and preferential subaerial chemical-weathering (Morton \& Hallsworth, 1999). Heavy minerals can broadly be subdivided into categories based on their inherent relative stabilities:

1. Ultra-stable (rutile, tourmaline and zircon). 
2. Deep-burial stability; garnet and apatite are stable during deep burial but are more

210 vulnerable to hydrothermal or acidic meteoric fluids.

211 3. Intermediate stability: epidote, kyanite, staurolite and titanite.

212 4. Less-stable: amphibole, olivine and pyroxene.

213 Heavy mineral indices are used in conjunction with the overall mineral assemblage to better

214 refine our prediction of source. These indices are based on pairs of heavy minerals, which

215 are chosen based on their stability during diagenesis and share similar hydraulic properties

216 (Morton \& Hallsworth, 1994). For the purpose of this study these indices include

217 apatite:tourmaline (ATi), garnet:zircon (GZi) and rutile:zircon (RZi).

218 Single-mineral geochemistry can provide greater detail on source-rock lithology. In this

219 study, the geochemistry of garnet and tourmaline are used to propose potential source

220 lithologies and to aid in the discrimination of basin sediments. Both mineral groups possess

221 a wide range of chemical compositions, which are dependent on their mode of formation

222 through variations in pressure and temperature.

\section{Garnet Speciation}

224 Attempts to assign a source lithology based on garnet geochemistry can be fraught with problems as certain species of garnets can be associated with differing paragenesis (Wright, 1938). Mange and Morton (2007) divided garnets into different classifications based on

227 their divalent $\mathrm{X}$-site cation $\mathrm{Mg}$ (pyrope), Fe+Mn (almandine/spessartine series) and Ca

228 (grossular/andradite series). They noted that the subdivision of garnets should be used to reflect natural sedimentary groupings and are not strictly indicative of a specific garnetbearing source rock. Mange and Morton (2007) divided garnets into four classifications

231 (Type A, B, C \& D). Type A garnets are typically derived from high-grade granulite facies, 
meta-sediments and charnockites. Type B garnets can be derived from amphibolite-facies meta-sediments, this type can be further divided into a type $\mathrm{Bi}$ group which can be

234 indicative of intermediate-acidic igneous rocks and $\mathrm{Bii}$ can be derived from metasedimentary rocks up to amphibolite facies; however, some compositional overlap

236 between the $\mathrm{Bi}$ and $\mathrm{Bii}$ groups may occur. Type $\mathrm{C}$ garnets are analogous of high-grade

237 metabasic rocks; type $\mathrm{Ci}(\mathrm{XMg}<40 \%)$ are more likely to be associated with meta-igneous

238 rocks such as eclogites, granulites and amphibolites (Fossum et al., 2019), whereas Cii garnets (XMg $>40 \%$ ) are likely to be associated with mantle-derived rocks (Fossum et al., 2019). Type D garnets are associated with metasomatic rocks such as skarns, from very lowgrade metabasic rocks or from ultra-high temperature metamorphosed calc-silicate

242 granulites.

243 The Aubrecht classification (Aubrecht, 2009) of garnets is used to denote metamorphic

244 grades $(A, B$ \& $C): A$ = garnets with compositions from HP-UHP conditions, $B=$ granulite to eclogite facies and $C_{1}=$ transitional field of garnet compositions from high amphibolite to granulite, $C_{2}=$ amphibolite facies (including garnets from blue-schists, skarns, serpentinites and igneous rocks).

Tourmaline Speciation

The tourmaline-supergroup consists of a complex suite of borosilicates sharing the common formula: $\mathrm{XY}_{3} \mathrm{Z}_{6}\left(\mathrm{BO}_{3}\right)_{3} \mathrm{Si}_{6} \mathrm{O}_{18}(\mathrm{OH})_{4}$ (Henry \& Guidotti, 1985; Yavuz et al., 2014). A common accessory mineral in many lithologies which is highly resistant to diagenesis and chemical weathering, tourmaline is a useful mineral for petrographic studies. Tourmaline can be subdivided based on two series; schorl-dravite and schorl-elbaite; compositional refinement is based on the four predominant substitution-elements ( $\mathrm{Al}, \mathrm{Ca}, \mathrm{Fe} \& \mathrm{Mg}$ ). Using the Al-Fe (tot) $\mathrm{Mg}$ and Ca-Fe (tot)-Mg ternary diagrams (Fig 10), some inferences on source-rock can 
be made, which include: Li-rich/poor granitoids and pegmatites, Ca-rich/poor metapelites,

257 meta-carbonates and meta-ultramafics.

258 Fieldwork

259 A total of 30 samples were collected for this study, documented in Table 1 (Appendix) and

260 locations shown in Fig 2. Samples from three major rivers were taken, two from the Senegal

261 River, two from the Saloum and five from the Casamance River. No samples were collected

262 from the Gambia River due to a lack of observed sand along the riverbank.

Sediment sampling from active river channels was restricted due to access and availability of exposed sand. The Senegal River (Fig 3D), located within Northern Senegal in the Saharan environment, had a bedload dominated by sands and the riverbanks are characterised by dense grasses and scrub. The Saloum River (Fig 3A) is located within the Sahel environment, which is typically arid with abundant scrub and baobab trees. This river was more accessible, however, much of the tributary upstream had dried-up, leaving only organic-rich muds and evaporates at the surface. The Gambia (Fig $3 C$ ) is a large river system with the channel reaching $12 \mathrm{~km}$ at the widest point. Accessibility was extremely limited due to extensive muddy mangrove swamps flanking the riverbanks and even feeder-tributaries

272 yielded no sand deposits for sampling. The sediment immediately surrounding the river and mangroves was typically composed of dark organic-rich clays.

274 The Casamance (Fig 3B) yielded better results, with several accessible sampling points along

275 the meandering river. The environment in this region was more sub-tropical, with grasses 276 and extensive gallery-forests flanking the river, many of these included vast areas of mango production. 
The sampling regime for river sediments involved collection of sand from pits dug ca. 30

$279 \mathrm{~cm}^{3}$, the size of pit was chosen to reflect an average detrital composition unaffected from seasonal variation in water-levels and flash flood events. The $30 \mathrm{~cm}$ depth includes the uppermost $(10 \mathrm{~cm})$ contemporaneous sedimentation layer (Okay \& Ergun, 2005) and the

282 lower $20 \mathrm{~cm}$ profile for better sample representativity (Pan et al., 2016). The sampling sites were selected in natural settings with no apparent anthropogenic influence, in order to collect 1-2 kg of sand. Where possible, multiple samples were collected from various points across the river-banks to remove any local variations in mineral assemblage due to hydraulic sorting. Due to a lack of sediments directly sourced from the rivers in some locations, extra samples were also taken from adjacent Cenozoic deposits in the form of exposures, pits and quarries (Fig 4), these were also difficult to find at times due to accessibility and the sheer scale of the distances involved in the sampling programme. Three sand pits were sampled along the Gambia's riverside, within the regions of Jenoi, Japp (Fig 4A) and Dalaba (Fig 4B). A large sand quarry located near the town of Tivaouane (77 km North-East of Dakar) was sampled containing massive units of structureless Miocene to Pliocene age sands (Fig 4E). A few exposures within this quarry exhibited transgressive lag-deposits (Nahon et al., 1977) containing sub-rounded lateritic clasts (Fig 4F). A smaller sand quarry near Thiago (Northern Senegal), east of Lake de Guiers, also yielded several samples of sand (Fig 4C, D). 


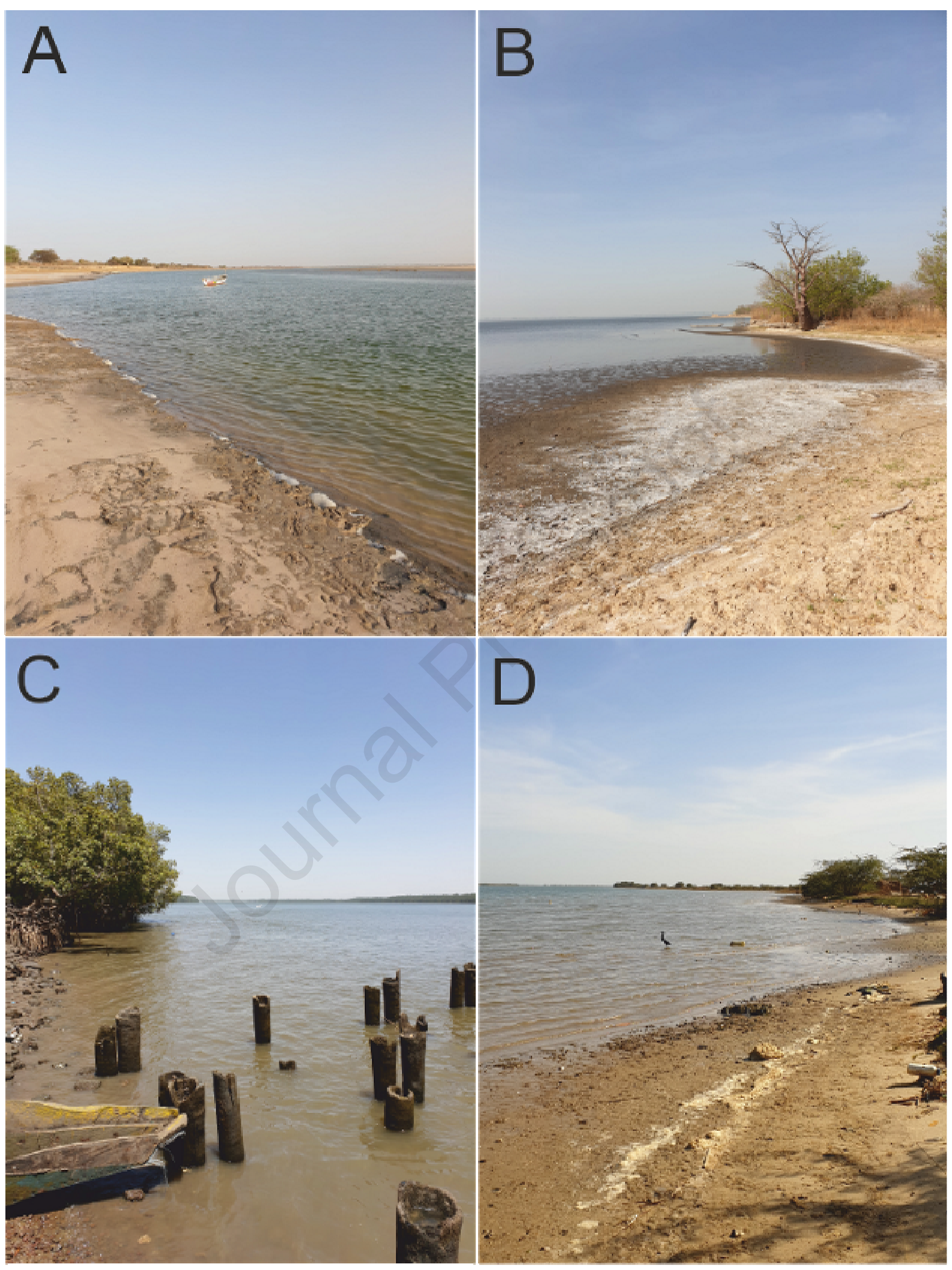

Figure 3A, Sand bank along the River Saloum, South of Kaolack. B Sand ban along the River Casamance at Diop Kounda. C Mud embankment along the River Gambia, North of Sankwin, dense mangroves border the river. $D$, Sand embankment along the River Senegal Northeast of Debi. 


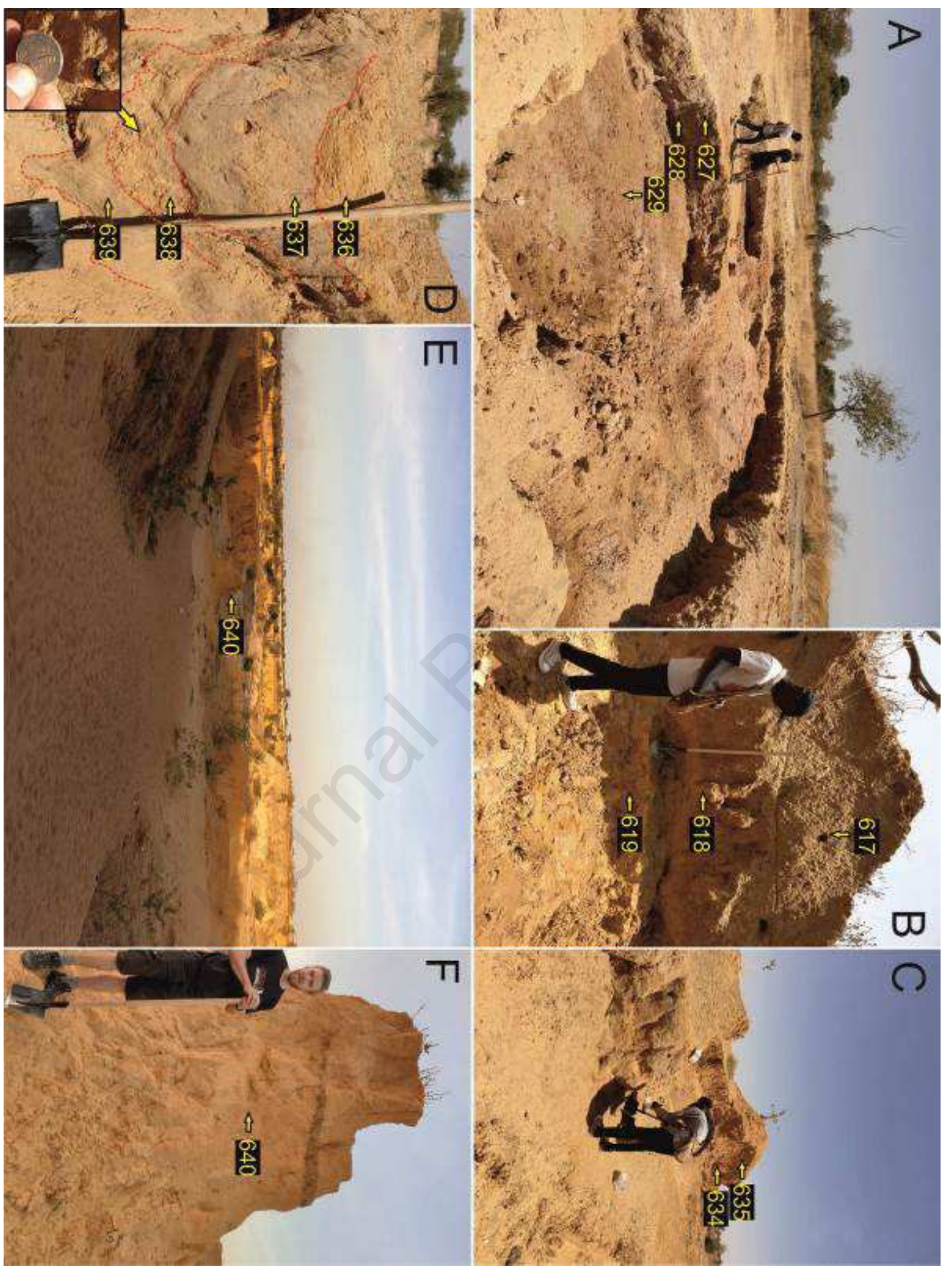

Figure 4, Photographs of Cenozoic sandstones with corresponding sample numbers and sampling locations. A, Japp sand pit, north of Sankwin, Gambia. B, Sandy exposure/pit near Dalaba, Gambia. C, Thiago quarry, Northern Senegal. Massive red/brown (upper unit), grey/brown (lower unit) sandstones in the background, studied outcrop in foreground is expanded in Figure 4D. D, fluvial sand deposits: 636, brown finely laminated sands. 637, grey/brown sand. 638, orange/brown, matrix-supported comglomeratic sand, with small $(<10 \mathrm{~mm})$ pieces of lignite/wood. 639, grey/brown sand. E, Tivaouane quarry, $77 \mathrm{~km} N E$ of Dakar, 640 marks the location of a sandstone pinicle which is explanded in Figure 4F. F, Orange/brown sandstone with a transgressive laterite lag-deposit. 
Conventional heavy mineral analysis

Heavy mineral separation was conducted on the $63 \mu \mathrm{m}$ to $125 \mu \mathrm{m}$ sand fraction (based on

310 the technique established by: Morton \& Hallsworth, 1994, Farrant et al., 2018). Analysis of

311 the transparent detrital heavy minerals (tdHM) was performed using a transmitted light

312 microscope (Mange \& Maurer, 1992; Farrant et al., 2018; Mounteney et al., 2017), averaging 300 tdHM per sample. Opaque heavy minerals were counted but not identified.

314 Petrography

315 Petrographic analysis was performed using the Gazzi-Dickinson method (Ingersoll et al., 316 1984), samples were impregnated in blue resin and polished to a thickness of $30 \mu \mathrm{m}$ and

317 stained for K-feldspar identification. Clast analysis of the sands and sandstones using a Qm-

318 F-Lt plot, was conducted on 300 sand-sized counts per sample, including the identification 319 of: monocrystalline and polycrystalline quartz, plagioclase and K-feldspar, lithic grains 320 (metamorphic, igneous and sedimentary), clay minerals (muscovite, biotite and chlorite),

321 carbonate, accessory minerals and fine-grained clay matrix (Ingersoll et al., 1984; Li et al., 322 2015; Dickinson et al., 1983).

323 Whole-rock mineralogy

324 Representative subsamples of the dried sands were ball-milled to reduce particle size to < $325125 \mu \mathrm{m}$. Subsamples of the $<125 \mu \mathrm{m}$ material were micronised under water for $10 \mathrm{~min}$ 326 with 10\% corundum (American Elements-PN:AL-OY-03-P) using a McCrone micronising mill 327 for bulk-rock mineralogical quantification (Kemp et al., 2016b; Collier et al., 2019). Bulk-rock 328 X-ray Diffraction (XRD) analysis was carried out using a PANalytical X'Pert Pro series 329 diffractometer equipped with a cobalt target tube, $X^{\prime}$ Celerator detector, and operated at 45 330 $\mathrm{kV}$ and $40 \mathrm{~mA}$. 
331

332 Separation of the $<2 \mu \mathrm{m}$ clay fraction for orientated-clay XRD analysis was achieved using the methods defined in Kemp et al., 2016a. The $<2 \mu \mathrm{m}$ oriented mounts were scanned from $2-40^{\circ} 2 \theta$ at $1.02^{\circ} 2 \theta /$ minute after air-drying, after glycol-solvation and after heating to $550^{\circ} \mathrm{C}$

335 for 2 hours. Quantification of the $<2 \mu \mathrm{m}$ clay was calculated based on the method defined by Biscaye (1965). The $<2$ um fraction is chosen because of the reasonable assumption that $100 \%$ of the mineralogy is constituted by chlorite, illite, kaolinite and smectite (Biscaye, 1965).

Single-mineral geochemistry

Samples were analysed using an FEI Company Quanta 600 scanning electron microscope

341 (SEM) fitted with an Oxford Instruments X-Max $50 \mathrm{~mm}^{2}$ silicon-drift energy dispersive X-ray

342 (EDX) detector running with Oxford Instruments INCA (v4) software. Analytical conditions

343 for the SEM were: high vacuum $\left(<10^{-4}\right.$ Torr), an accelerating voltage of $20 \mathrm{keV}$, and a spot

344 size of 6 (beam current $\sim 2 \mathrm{nA}$ ).

345 Automated quantitative microanalysis and mineral identification was performed using the

346 'Feature' package within the INCA software. Multiple images were obtained over a mm-

347 scale grid with the backscatter electron (BSE) technique. Since the brightness of a phase under BSE imaging is proportional to its mean atomic number, greyscale thresholding was used to limit microanalysis to grains with similar average greyscale values to that of a known tourmaline. Microanalytical EDX data was obtained from a centre-point site of each of the threshold-identified grains, determined as the centre of the longest chord (a straight line

352 that can be drawn entirely within the grain boundary). 
354 Zircon U-Pb data was acquired using a Nu Plasma HR multi-collector inductively coupled

355 mass-spectrometer. Sample were introduced into the mass spectrometer using New Wave 356 Research UP193SS solid state laser ablation.

357 All analyses were carried on a $25 \mu \mathrm{m}$ spot, with a frequency of $10 \mathrm{~Hz}$, resulting in a fluence 358 of c. $2.0-2.5 \mathrm{~J} / \mathrm{cm} 2$. Samples were ablated for 30 seconds. Ablated sample material was 359 transported to the mass spectrometer by a flow of He gas, which was continuously passed 360 through the sample cell. Data were acquired and processed using the Nu Instruments time 361 resolved analysis software, and the lolite 3 data reduction package (Paton et al, 2011). Data 362 was is exported using IsoplotR software (Vermeesch, 2018). For zircon analysis, the matrix 363 matched zircon standard 91500 was analysed throughout each session and used as the 364 primary standard for data reduction. The analytical uncertainties for each sample ratio are 365 propagated relative to the reproducibility of this standard. Additional zircon standards 366 (Plesovice and GJ1) were analysed at regular intervals during each session. 
Results

369 Heavy mineral analysis.

370 Results from the heavy mineral analysis are illustrated in Figure 5, heavy mineral indices are

371 displayed in Figure 6 and the raw data found in the Appendix. Sediments can be categorised

372 into two provenance-groups based on their tdHM assemblages. The first provenance group

373 is associated with sands from the Senegal River, yielding the most distinctive heavy mineral

374 assemblage, with an average tdHM composition of: amphibole (17\%), clinopyroxene (4\%),

375 epidote (19\%), garnet (2\%), staurolite (5\%), tourmaline (10\%) and zircon (40\%). The second

376 provenance-group is associated with the remaining samples that possess similar tdHM

377 assemblages comprising of: rutile (4-11\%), staurolite (1-11\%), tourmaline (4-32\%) and zircon

378 (49-89\%). This rutile, staurolite, tourmaline and zircon dominated assemblage is analogous

379 of a "mature" heavy mineral component, whereby the less-stable heavy minerals are

380 removed through mechanical abrasion, chemical weathering and diagenesis. Minor

381 variations in the tdHM compositions include low concentrations of clinopyroxene in the

382 Tivaouane quarry and epidote in the Thiago quarry. The differences in the bulk tdHM (Fig 5)

383 are exemplified by the corresponding GZi, ATi and RZi (Fig 6), displaying a significant shift in

384 the GZi associated with the River Senegal tdHM. There were no significant differences in the

385 quantitative mineralogy for multiple samples collected across the river-bank, inferring good

386 sample representivity. 


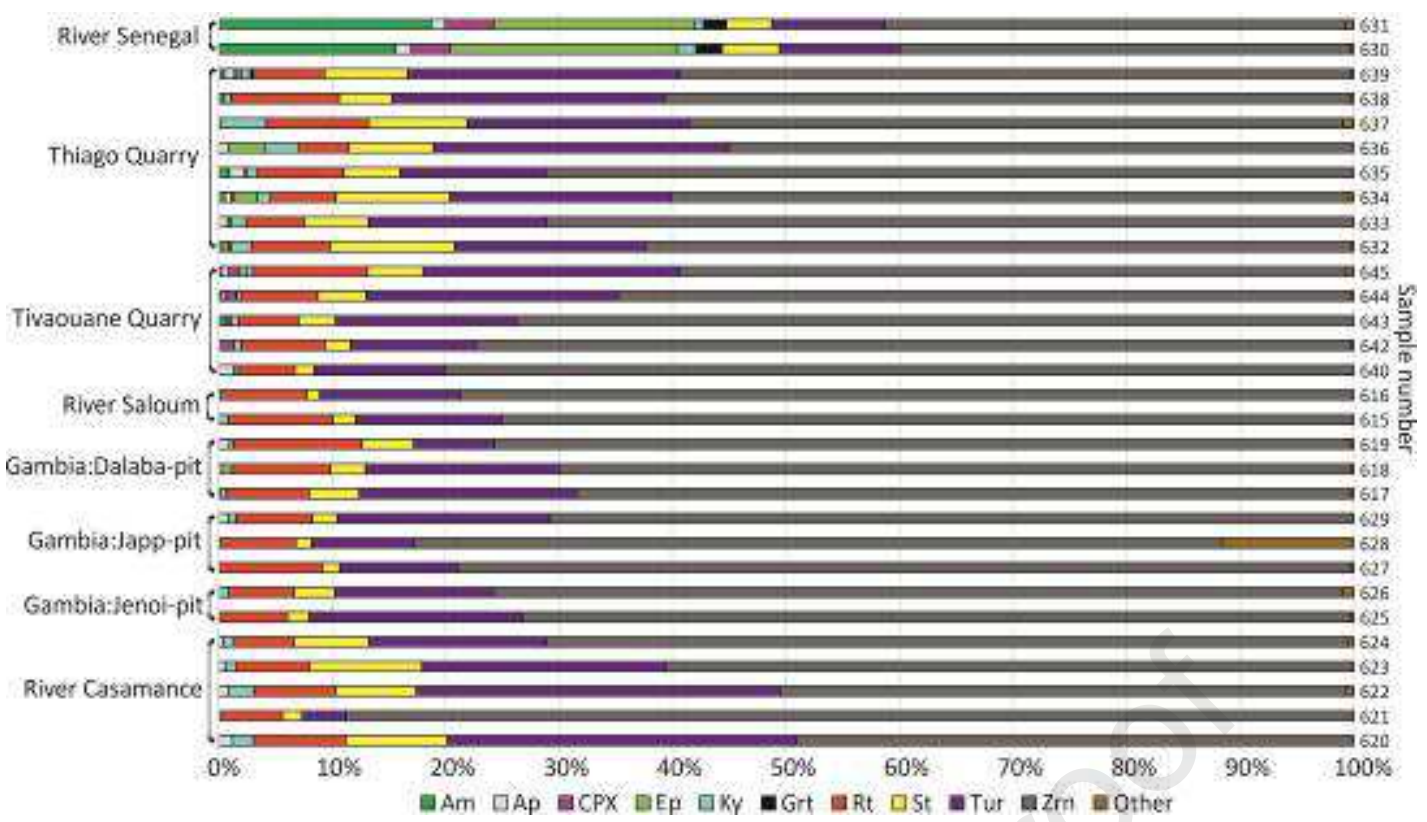

Figure 5, Transparent detrital heavy mineral assemblages, opaque minerals have been excluded.

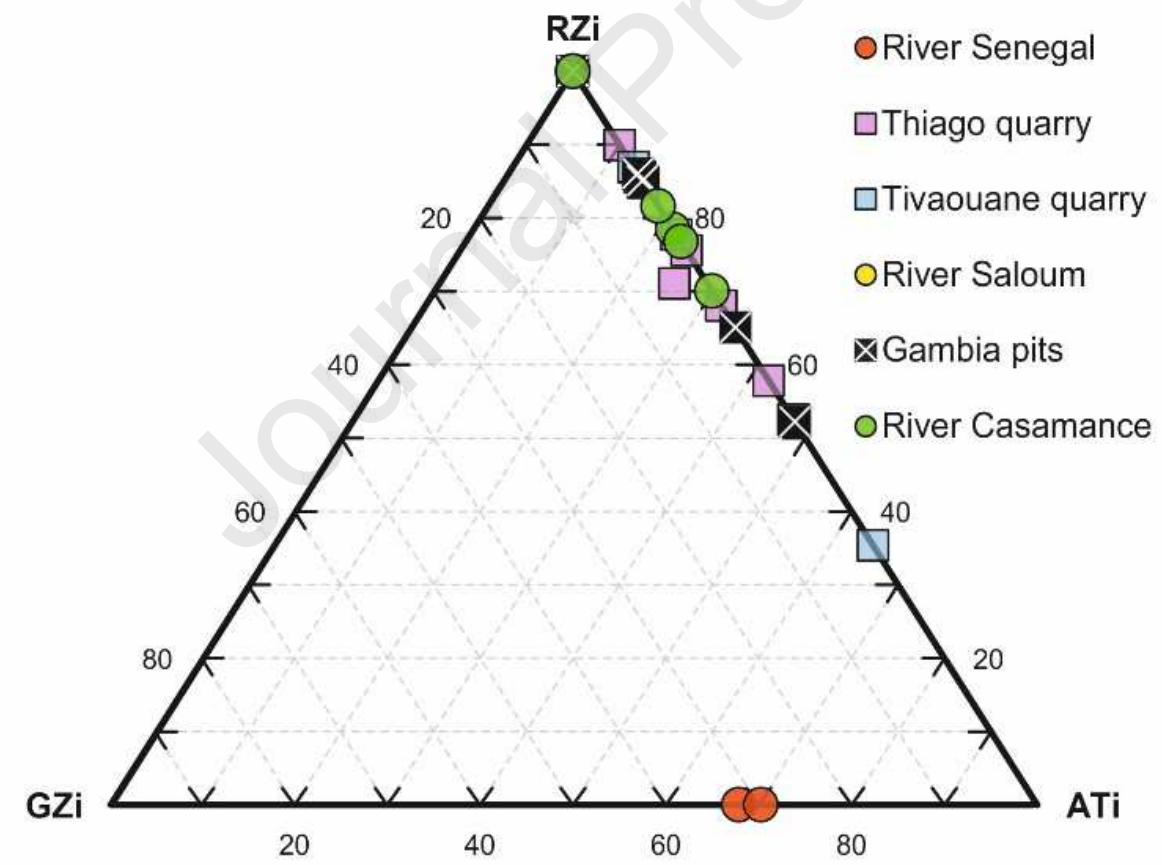

Figure 6, Rutile:zircon-index (RZi), garnet:zircon-index (GZi) and apatite:tourmaline-index (ATi) ternary plot.

392 Whole-rock mineralogy

393 XRD results are fully documented in the Appendix. All samples are predominantly 

smectite) and kaolinite $0.7-1.4 \%$. Other trace minerals $(<5 \%)$ include: bassanite, gypsum, goethite, hematite and halite.

399 The results of $<2 \mu \mathrm{m}$ clay mineral XRD analysis are summarised in Figure 7 . The clay mineral assemblages can be subdivided into two distinct regions: northern Senegal (Senegal River and Thiago quarry) and mid to southern Senegal (Casamance \& Saloum rivers and quarry/pit samples from The Gambia and Tivaouane quarry).

The Northern Senegal $<2 \mu \mathrm{m}$ clay assemblage is predominantly composed of kaolinite (47.9-

Tivaouane are entirely devoid of smectite.

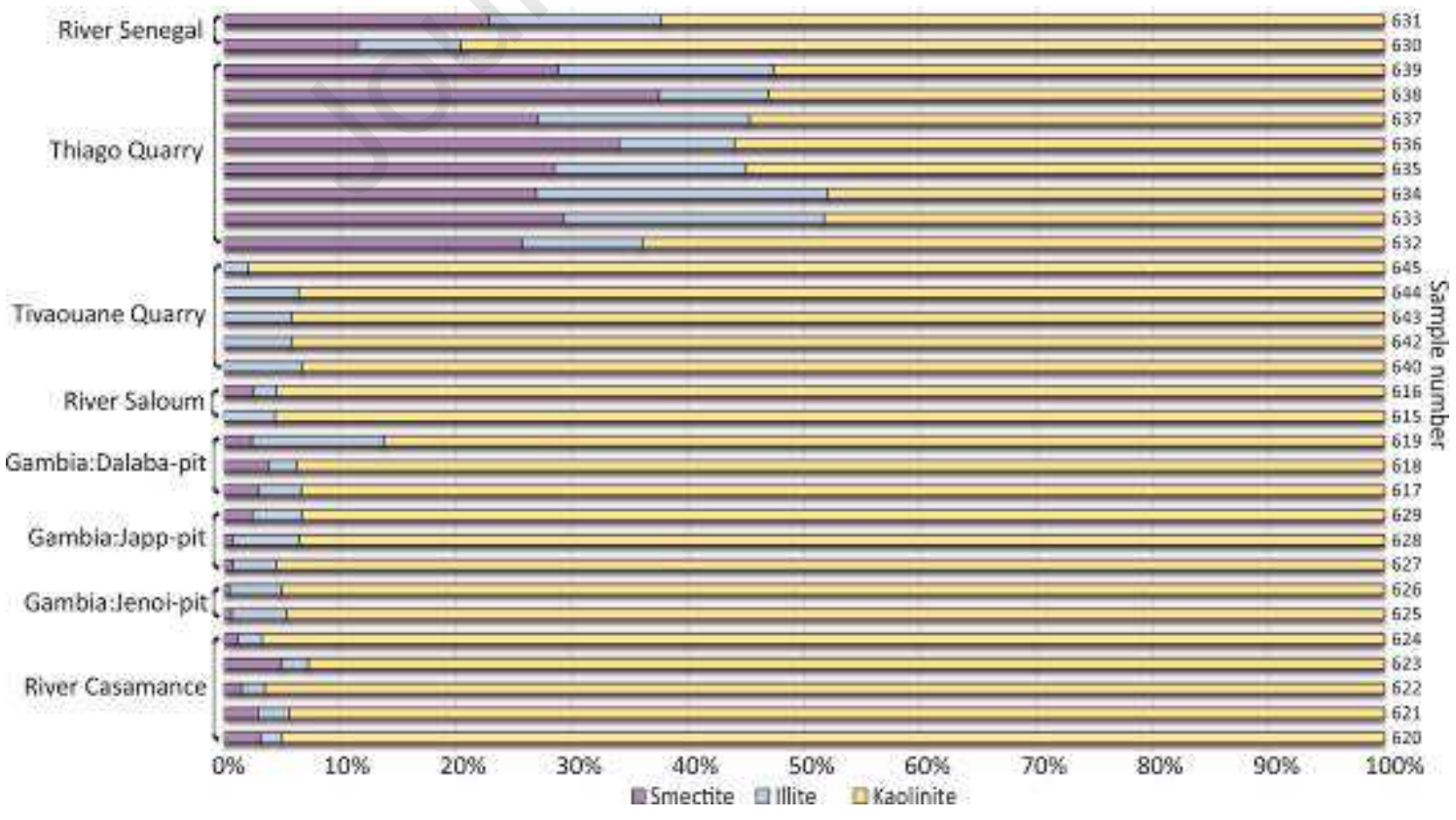


410 Single-mineral geochemistry

411 Garnet speciation is restricted to the sediments collected from the Senegal River, due to an

412 absence of garnet in all of the other samples and is limited to $2 \%$ of the $63-125 \mu \mathrm{m} \mathrm{tdHM}$. A

413 total of 201 garnet grains were identified by SEM, the majority classified as Type B i \& ii

414 garnets, according to the scheme devised by Mange and Morton (2007) (Fig 8A). They

415 reflect one or more of the following source lithologies: amphibolite-facies, metasedimentary

416 rocks, intermediate to felsic igneous. A lesser proportion of garnets is represented by Type

417 D garnets which reflect a metasomatic source. Finally, 2.5\% of the remaining garnets

418 reflect a Type $\mathrm{Ci}$ source, analogous of a meta-igneous source, such as eclogites, granulites

419 and amphibolites. According the Aubrecht classification scheme (Fig 8B \& C) most of the

420 garnets were formed in the C field, which can include garnets from high-grade amphibolite

421 facies, granulites, blue-schists, skarns, serpentinites and igneous rocks. A small percentage

422 of garnets plot within the B field and represent granulite to eclogite facies. 


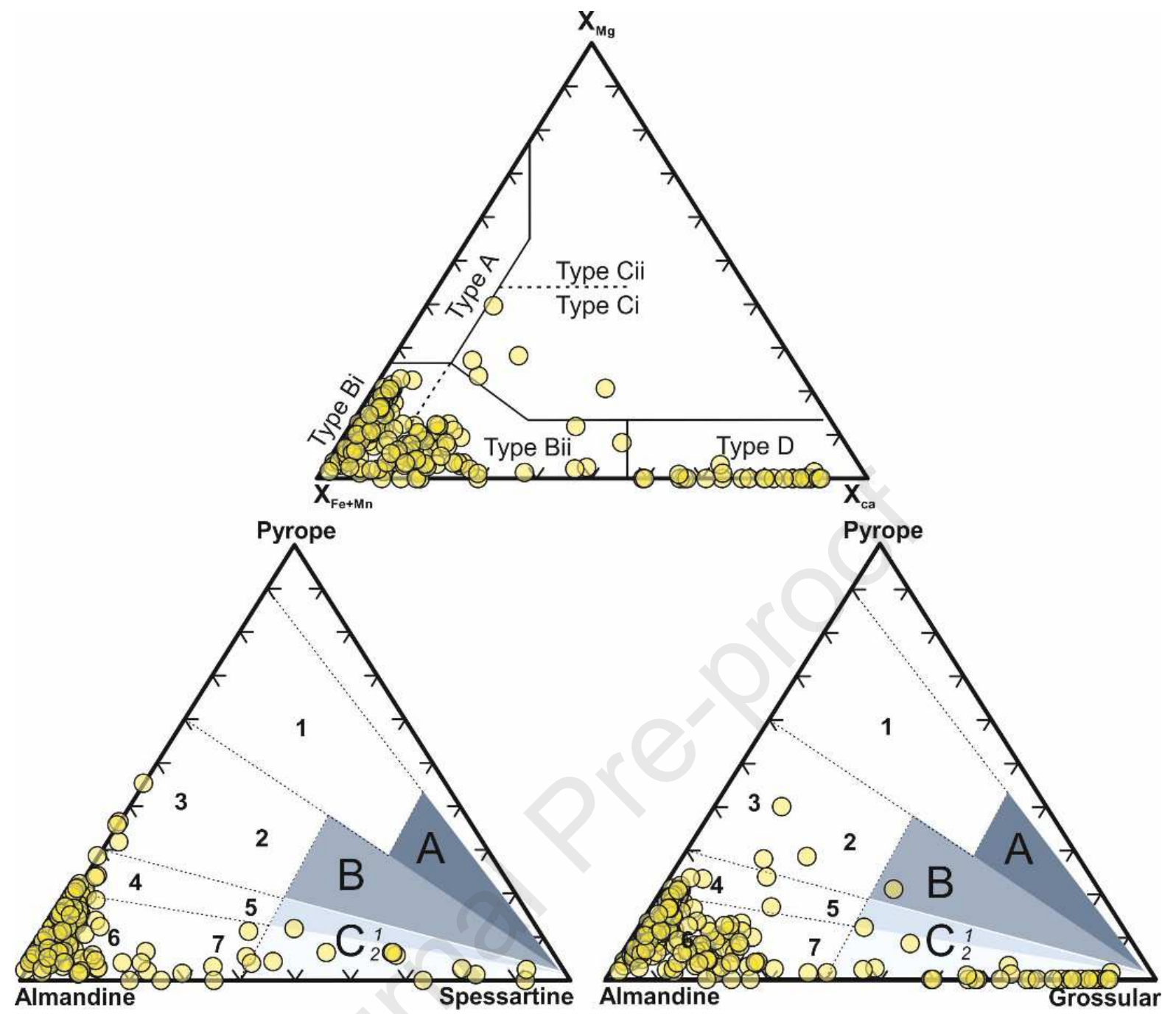

424 Figure 8, Garnet-speciation ternary diagrams, data from SEM-based geochemical analysis of 63-125 $\mu \mathrm{m}$ tdHM from the Senegal River sands (sample 630). A, Garnet speciation based on the classification scheme by Mange and Morton (2007). Type-A= high-grade granulite-facies metasediments or charnockites and intermediate felsic igneous rocks, Type- $B=$ amphibolite-facies metasedimentary rocks, Bi= intermediate to felsic igneous rocks, $\mathrm{Ci}=$ high-grade mafic rocks, Cii= ultramafics with high $\mathrm{Mg}$ (pyroxenites and peridotites), $D=$ metasomatic rocks, very low-grademetamafic rocks and ultrahigh temperature metamorphosed calc-silicate granulites; $B$ \& C, Garnet speciation based on the classification scheme after Aubrecht et al., 2009: A= garnets from high-pressure to ultrahigh-pressure rocks, $B=$ garnets from eclogite and granulite facies rocks, $C=$ garnets from amphibolite-facies rocks. The group $C$ is further subdivided into two subgroups. The transitional field $C_{1}$ includes garnets from higher amphibolite to granulite-facies rocks whereas the field $C_{2}$ includes garnets from amphibolite-facies rocks but also includes garnets other rocks such as blueschists, skarns, serpentinites and igneous rocks. The source lithologies for garnets are distinguished into 7 groups. (1) garnets derived from UHP eclogites or garnet peridotites, (2) garnets derived from HP eclogites and HP mafic granulites, (3) garnets derived from felsic and intermediate granulites, (4) garnets derived from gneisses metamorphosed under pressure and temperature conditions transitional to granulite and amphibolite-facies metamorphism, (5) garnets derived from amphibolites metamorphosed under pressure and temperature conditions transitional to granulite and amphibolite-facies metamorphism, (6) garnets derived from gneisses metamorphosed under amphibolite-facies conditions, (7) garnets derived from amphibolites metamorphosed under amphibolite-facies conditions.

441 Tourmaline speciation was performed on a total of six samples from: the Senegal,

442 Casamance and Saloum Rivers, Thiago, Tivaouane quarries and Gambia Jenoi (Fig 9). River

443 Senegal tourmalines are predominantly Fe-endmember schorl/buergerite, indicative of a 
444 primary Li-poor granitoid, pegmatite and aplite source-lithology. Minor variations in $\mathrm{Al}_{\text {tot }}{ }^{-}$ 445 AlFe $_{50-A l M g} \mathrm{Al}_{50}$ (Fig 9) ratios infers a potential secondary source-lithology for the 446 schorl/buergerite including metapelites, metapsammites and Fe-rich quartz-tourmaline 447 rocks including calc-silicate rocks and metapelites. Tourmalines from the remaining sample 448 sites, including the Casamance and Saloum Rivers, Thiago and Tivaouane Quarries and 449 Gambia Jenoi possess similar endmember tourmalines. The majority of the tourmalines are 450 divided between Fe-endmember schorl/buergerite and Mg-endmember dravite (Fig 9) and 451 are indicative of a primary Li-poor granitoid, pegmatite and aplite source and potential 452 secondary source-lithologies of metapelites, metapsammites and Fe-rich quartz-tourmaline 453 rocks including calc-silicate rocks and metapelites. A small percentage of tourmalines plot

454 within or very close to oxy-dravite endmember (Fig 9) which could be diagnostic of Low-Ca 455 metaultramafics and $\mathrm{Cr}, \mathrm{V}$-rich metasediments. 


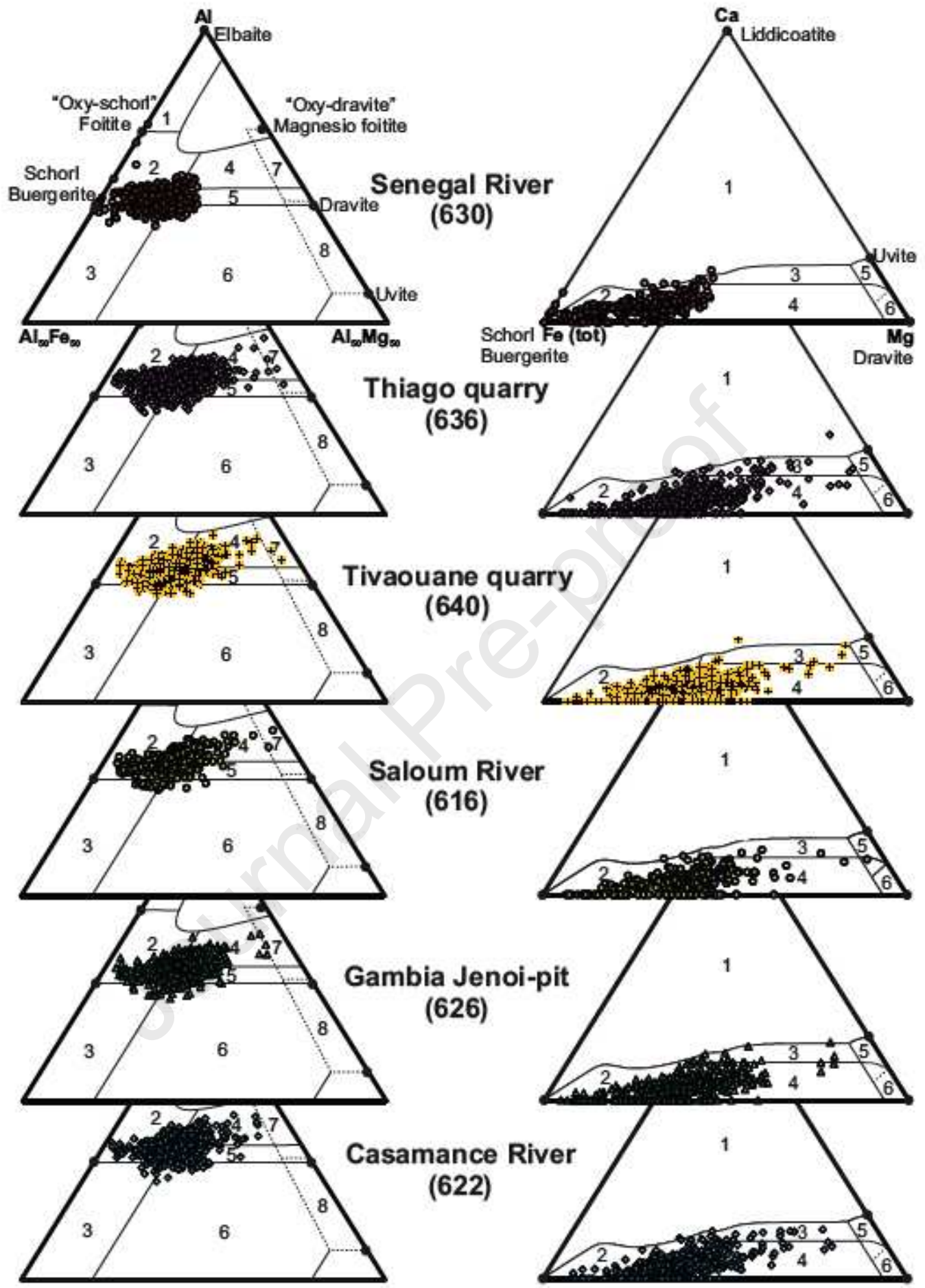

Figure 9, Compositional ternary diagrams of tourmalines, illustrating the host rock type (from Henry \& Guidotti, 1985). Left $\left(\mathbf{A l}-\mathrm{Fe}_{\text {tot }}-\mathbf{M g}\right): \mathbf{1}=$ Li-rich granitoid pegmatites and aplites, $2=L i$-poor granitoids and their associated pegmatites and aplites, $3=\mathrm{Fe}^{3+}$ rich quartz-tourmaline rocks (hydrothermally altered granites), $4=$ Metapelites and metapsammites coexisting with an Al-saturating phase, $5=$ Metapelites and metapsammites not coexisting with an Al-saturating phase, $6=$ $\mathrm{Fe}^{3+}$ rich quartz-tourmaline rocks, calc-silicate rocks, and metapelites, $7=$ Low-Ca metaultramafics and Cr, V-rich metasediments, $8=$ Metacarbonates and meta-pyroxenites. Right $\left(\mathbf{C a}-\mathrm{Fe}_{\text {tot }}-\mathrm{Mg}\right)$ : $1=$ Li-rich granitoid pegmatites and aplites, 2= Li-poor granitoids plus associated pegmatites and aplites, $3=$ Ca-rich metapelites metapsammites and calcsilicate rocks, $4=$ Ca-poor metapelites metapsammites and quartz-tourmaline rocks, $5=$ Metacarbonates, $6=$ 
Petrography

467 Clast analysis suggests the river sands and Cenozoic sandstones are compositionally similar,

468 exhibiting the high textural maturity of a quartz-arenite (Fig S 2). On average, 83\% of the

469 component grains identified were monocrystalline quartz with $6 \%$ polycrystalline quartz, $9 \%$

470 fine grained clay, $1 \%$ feldspar ${ }_{\text {tot, }} 1 \%$ lithic $_{\text {tot }}$ and $1 \%$ accessory mineral. Based on the

471 subdivisions devised by Dickinson et al., (1983), all the modern-day sediments may be

472 associated with the erosion of a cratonic interior. Whilst this may reflect a cratonic source,

473 this quartz enrichment may be exacerbated through associated weathering, transport and

474 diagenesis within a tropical climate (Garzanti, 2017).

$475 \mathrm{U} / \mathrm{Pb}$ zircon dating

$476 \mathrm{U} / \mathrm{Pb}$ dating was performed on a suite of zircons from the Senegal and Casamance rivers and

477 from Quaternary sandstone from within the Gambia paleo-river system. Kernal density 478 estimation (KDE) plots (Fig 10) were constructed using IsoplotR (Vermeesch, 2018). All three 479 samples have a strong Pan-African age (500-650 Ma) population of zircons and a 480 comparable Paleo-Proterozoic age (1600-2500 Ma) zircon population. The Senegal River 481 have far fewer Meso-Proterozoic age zircons and a small population of Neo-Archean age 482 (2600 Ma) zircons. The Gambia River contains the oldest population of Meso-Archean 483 zircons (3100 Ma). The River Casamance has the youngest population of zircons at $200 \mathrm{Ma}$. 

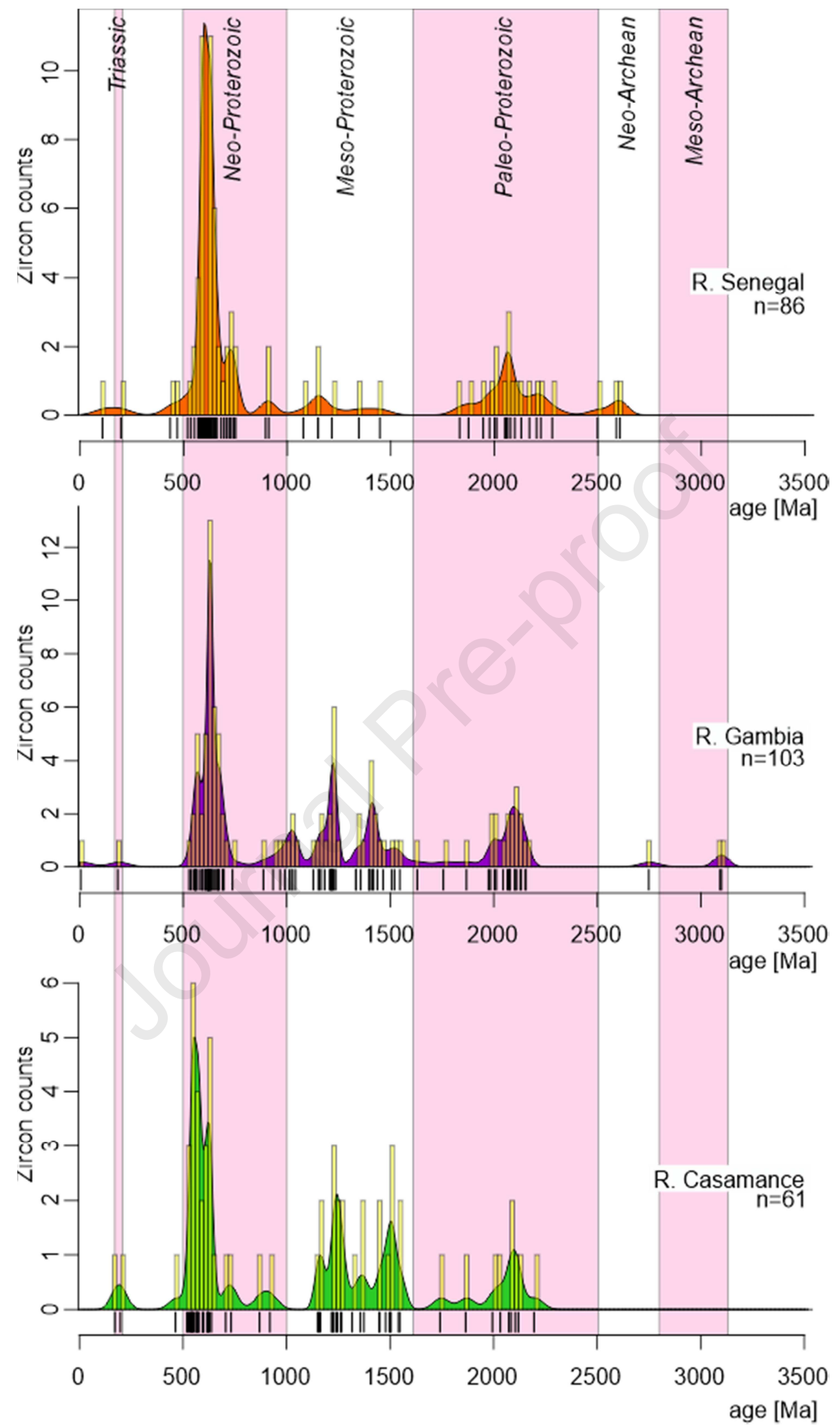
488 Heavy mineral analysis of the sediments from the River Senegal are displayed in Figure 5.

489 The defining heavy minerals include: amphibole, clinopyroxene, epidote and garnet. The 490 presence of these heavy minerals is indicative of a low-medium grade metamorphic source, 491 such as green-schist facies (Villeneuve, 2008; Page, 1987; Markwitz et al., 2015). This is 492 further supported by Michel (1973) who suggests that the Senegals' erosional catchment 493 includes: Precambrian and Paleozoic schists, sandstones, basic volcano-sedimentary complexes and syntectonic Birimian granites emplaced within the metamorphic series appear throughout the western WAC, Fouta Djallon Plateau, and the KKI. The Falémé erosional catchment also includes Precambrian schists, a volcano-sedimentary complex and granites. This is further supported by the abundance in Type B garnets (Fig $8 \mathrm{~A}$ ), suggestive of a metasedimentary source-lithology (Mange and Morton, 2007). Tourmaline discrimination (Fig 9) indicates the Senegal River sediments are predominantly Fe-end member 500 schorl/buergerite, indicative of a primary Li-poor granitoid, pegmatite and aplite source501 lithology. Minor variations in $\mathrm{Al}_{\text {tot }}-\mathrm{AlFe}_{50}-\mathrm{AlMg}_{50}$ (Fig 9) ratios suggest a potential secondary 502 source-lithology for the schorl/buergerite including metapelites, metapsammites and Ferich quartz-tourmaline rocks including calc-silicate rocks and metapelites. The $<2 \mu \mathrm{m}$ clay

504 mineralogy is predominantly kaolinitic with moderate smectite and illite. Sediments from 505 Thiago quarry possess a similar clay mineralogy with the presence of significant amounts of

506 smectite being the defining constituent. However, despite the similarities in clay 507 mineralogy, the Thiago quarry tdHM assemblages are significantly different, comprising 508 rutile, staurolite, tourmaline and zircon with minor amounts of apatite, epidote and kyanite.

509 This assemblage is comparable with the tdHM assemblages of the Tivaouane, Saloum, 510 Gambia and Casamance regions to the south (Fig 5) and is representative of a "mature" 
heavy mineral assemblage. The tourmalines associated with this "mature" tdHM suite

512 possess similar endmember tourmalines. The majority of the tourmalines are divided

513 between Fe-end member schorl/buergerite and Mg-end member dravite (Fig 9) and are

514 indicative of a primary Li-poor granitoid, pegmatite and aplite source and potential

515 secondary source-lithologies of metapelites, metapsammites and Fe-rich quartz-tourmaline

516 rocks including calc-silicate rocks and metapelites. A small percentage of tourmalines plot

517 within or very close to oxy-dravite endmember (Fig 9) which could be diagnostic of Low-Ca

518 metaultramafics and $\mathrm{Cr}$, V-rich metasediments.

\section{Discussion}

520 Sediment supply to Northern Senegal

521 The principal source region for the sediments in the Senegal River is southwest Mali and southern Mauritania, where the Senegal Rivers' catchment is at its largest. More specifically the source is likely associated with denudation of the Mauritanides and the western margin of the WAC, between the Reguibat Shield in the north and the Leo Man Shield in the south (Gueye et al., 2007). The Mauritanide Belt contains Pan African I basement rocks including granites, quartzites and staurolite/garnet-grade mica schists (Villeneuve, 2008), plus eclogite

527 facies of pyroxenites and amphibole-pyroxenites (Dia, 1984). Neoproterozoic and Palaeozoic 528 age thrust-sheets within the Hercynian Belt are limited to greenschist facies (Villeneuve, 2008; Page, 1987; Markwitz et al., 2015). The Kédougou-Kéniéba Inlier (KKI) (Fig 2)

530 underwent transcurrent deformation along a network of ductile shear-zones (Ledru et al., 531 1991; Milési et al., 1992) during the Late Eburnean orogeny (Paleoproterozoic), 532 metamorphosing almost all the lithostratigraphic units under greenschist facies (Gueye et al., 2007). These greenschist facies of the KKI are also host to various deposits of skarn-type 
Skarn-type mineralisation within the KKI could account for the Type D garnets (Fig 8) which are associated with a metasomatic source-lithology.

$537 \mathrm{U} / \mathrm{Pb}$ dating of the Senegal River zircons (Fig 10) further supports the sediment source of the 538 Neo-Proterozoic Mauritanides (Gueye et al., 2007) and the Paleo-Proterozoic lithologies of 539 the KKI (Gueye et al., 2007). A small population of Neo-Archean age zircons may represent 540 the denudation of Archean TTG (tonalite-trondjemite-granodiorite) gneisses (Rollinson, 541 2016; Pawlig et al., 2006; Gueye et al., 2007) from within the northernmost limit of the 542 western segment of Leo-Man Shield (the Kénéma-Man domain; Gunn et al., 2018).

543 The smectite component is associated with a terrigenous supply and suggestive of a detrital source from non-diagenetic deposits derived from poorly drained soils (Chamley et al., 1988). Smectite development is favoured within arid, high-relief terrains, where climate, weathering-duration and groundwater-conditions are optimal, inhibiting chemical weathering (McKinley et al., 2003). Given the nature of development and the time required

548 for a significant accumulation of smectite without concurrent erosion and transportation;

549 generation of this smectite could have occurred during the Pleistocene hyper-arid period.

550 The principle source for the sands at Thiago quarry are interpreted to be the Meso-Cenozoic sediments from the onshore Senegalese basin, having been eroded and transported by the

552 Ferlo River. However, this would not account for the smectite component, whose proposed source is within the Mauritanides and Western WAC, transported via the River Senegal. This

554 can be explained through overbank flooding of the River Senegal into the adjacent Lake de 555 Guiers; when the maximum extent of the floodplain was reached (Pacini \& Harper, 2016).

556 Overbank flooding may have occurred during either the first or second AHP during the 557 Holocene, supported by documented evidence of increased sea-level (Miller et al., 2005), swelling of NW African lakes (Coutros, 2019; Armitage et al., 2015; Lézine et al., 1990) and 
the breaching of the Pleistocene dune-fields by the River Senegal at the entrance to the

560 Atlantic Ocean (McIntosh et al., 2016; Hamerlynck \& Duvail, 2003). This suggests the

561 Senegal River and Lake de Guiers were interconnected and overbank flooding will have

562 undoubtedly occurred along most of the middle Senegal valley. In this model, coarse clastic

563 sediments of the Senegal River would continue to be transported within the high energy

564 region of the river. However, the very fine-grained smectite would remain within the

565 suspended load, entering the Lake de Guiers-system through overbank-flooding, mixing with uncemented sands deposited within the Lake de Guiers system via the Ferlo River.

567 Evidence for variations in fluvial-energy was observed at Thiago quarry (Fig 4D), where sandstone rip-up clasts demonstrate localised incision of the floodplain. The presence of

569 lignite requires an ephemeral switch-off of the high-energy regime and overloading of the sediment column to be deposited due to their low density.

571 Recycling in Central and South Senegal

572 Whilst the provenance assemblage indicates that the Senegal River sources fresh detritus

573 from as far away as western Mali ca. $800 \mathrm{~km}$; the data from the Ferlo, Saloum, Gambia and

574 Casamance rivers suggest a more confined catchment, restricted to the interior of the

575 onshore Senegalese basin. The sediments collected all possess very similar tdHM assemblages exhibiting a "mature" heavy mineral component of rutile, staurolite tourmaline and zircon (Fig 5). The occurrence of staurolite (1-11\%) and kyanite (1-4\%) are indicative of a low-medium grade metamorphic source-lithology, therefore it is conceivable that garnet may also have been present in the original assemblage, despite its absence in the observed

580 mineralogy. The lack of apatite and garnet in the heavy mineral component suggests the sediment may have undergone extensive chemical-weathering, due to the mineral's relative 
garnet and apatite may have occurred during temporary alluvial storage and records the

584 subaerial exposure and recycling of the basins' sediments (Morton et al., 2013).

585 Alternatively, the sediments may be devoid of garnet due to the potential absence of garnet

586 within the inherent source-lithology.

587 In a comparative study of the Tarfaya basin (SW Morocco), sediments were considered to be

588 sourced from the Reguibat Shield, Mauritanides and Anti-Atlas Mountains (Ali et al., 2014;

589 Arantegui, 2008). Heavy minerals analysed from the Tarfaya basin exhibit garnet

590 throughout the Early Cretaceous and the Miocene-Pliocene, despite indicated variations of

591 intense chemical weathering (Ali et al., 2014). The difference in preserved heavy mineral

592 profiles between the Tarfaya and Senegal locations could be due to preferential chemical-

593 weathering of recycled apatite and garnet, which is more favourable within the Sahel

594 climate of Senegal than the Saharan climate of Morocco (Bateman \& Catt, 2007; Van-Loon \&

595 Mange, 2007).

596 The presence of staurolite and kyanite, plus the inferred garnet ( \pm apatite?) subsequently

597 lost to weathering, remains suggestive of a low to medium grade source lithology, similar to

598 the staurolite/garnet-grade micaceous schists of the Hercynian Belt (Villeneuve, 2008).

599 Assuming the source-terrain for the sediments of the onshore Senegalese basin is analogous

600 to the source of the modern-day Senegal River, the absence of amphibole, epidote and

601 pyroxene should be expected. Amphibole, pyroxene and epidote are amongst the least

602 stable of the heavy minerals under deep-burial conditions and chemical weathering

603 (Morton, 1984). Amphibole and pyroxene are both extremely susceptible to deep-burial

604 diagenesis and chemical weathering, whilst epidote is moderately susceptible to both these

605 conditions (Morton, 1984). Depending on the diagenetic bias of an individual basin, epidote 
can remain stable at depth ca. 1-2 km, with partial dissolution expected at depths of $c a .2-$

$3.5 \mathrm{~km}$ and total dissolution occurring at depths of ca. $3.5 \mathrm{~km}$ (Garzanti \& Andò, 2019).

Therefore, the lithological-source for the recycled basin sediments (transported via the Ferlo, Saloum, Gambia and Casamance rivers) is potentially the same region as that of the

610 Senegal River, including unspecified granites, low-medium grade metamorphic rocks and

611 greenschist facies. Subtle variations in tourmaline speciation is suggestive of a shift from a

612 mixed metasedimentary/granitic source in the recycled Meso-Cenozoic sediments of the

613 Ferlo, Saloum, Gambia and Casamance rivers in the Senegal basin, to a principally granitic-

614 type tourmaline source for the Senegal River sediments. With a degree of overlap between the tourmaline species of Meso-Cenozoic and modern-day sediments, it is plausible that this

616 is representative of an unroofing-trend of the western-margin of the WAC. The tourmalines

617 which are associated with a predominantly metasedimentary lithological source may be

618 diagnostic of a comparatively younger Hercynian belt, whilst the principally granitic-type

619 tourmalines of the Senegal River may be associated with the foremost erosion of older Pan

620 African Granites of the Mauritanides. The predominance of kaolin within the recycled basin

621 sediments is interpreted to originate from chemical-weathering and erosion of lateritic soils

622 and pedogenic kaolinitic deposits. Concentrations of up to $70 \%$ kaolin within the $<2 \mu \mathrm{m}$ clay

623 fraction are a common occurrence in Quaternary basin sediments of North Africa during

624 humid periods (Ehrmann et al., 2017). U/Pb dating of zircons from the Gambia and

625 Casamance River provinces show broadly comparable Neo-Proterozoic and Paleo-

626 Proterozoic populations, representative of a Mauritanide and KKI source. However, there is

627 a small population of Archean age zircons from the Gambia River province and whilst this

628 population of zircons is only minor, it may reflect a paleo-Gambia River which might have

629 eroded deep into the interior of the Leo-Man shield during the Mesozoic. The lack of 

zircons may infer a slightly different source area for a paleo-Casamance. With the possibility that a paleo-Gambia sourced sediment from the Leo-Man Shield during the Mesozoic, it is also possible that if a paleo-Casamance existed during the Mesozoic, it may also have sourced sediment south of Senegal. This can be corroborated by the occurrence of the (pyroclastics and lava flows) and intrusive (sills and dykes) low-Ti continental flood basalts

637 (Youbi et al., 2011). Whilst the full extent of the CAMP large igneous province (LIP) remains unclear in NW Africa, there is evidence to suggest that increases in mantle temperatures which led to the formation of the CAMP LIP approximately 200 Ma encompassed much of NW Africa (Whalen et al., 2015). Several studies have located CAMP dyke and sill swarms within the WAC, principally in the Leo-Man Shield, but also within the Reguibat Shield and the Taoudeni basin (Youbi et al., 2011; Gunn et al., 2018: Whalen et al., 2015).

Miocene to Pliocene sediments of Tivaouane quarry

644 The sands sampled at the Tivaouane quarry (Fig 2) are Miocene to Pliocene age Cuirasse 645 sandstones located within the plateau de Thiès succession (Roger et al., 2009; Pascal \& 646 Sustrac, 2005; Flicoteaux, 1982). Below these sands are the Eocene phosphate deposits of 647 the Lam Lam and Taiba Formations. The massive orange/brown Cuirasse sands (Fig 4 E\&F) 648 were likely deposited in a very shallow marine environment, evidence by transgressive 649 lateritic lag deposits (Fig 4 F) and the absence of smectite from the $<2 \mu$ m clay mineralogy, due to the hydraulic winnowing of sediment by wave action. During the Miocene and

651 Pliocene, rises in global sea-levels fluctuated from ca. 5 to $25 \mathrm{~m}$ above current levels (Miller et al., 2005). Senegal's current coastal and river-plain elevation is ca. $<41 \mathrm{~m}$ above sea-level

653 (Fig 1), this may have been lower during the Miocene and Pliocene allowing for the 
development of a shallow marine environment. The heavy mineral component of the

\section{5}

Cuirasse sandstone exhibits a "mature" heavy mineral component which includes rutile,

656 staurolite tourmaline and zircon. This heavy mineral component is analogous to the recycled Meso-Cenozoic sediments from the Thiago quarry, Saloum, Gambia and Casamance regions.

658 The absence of the heavy minerals which could be indicative of fresh detritus sourced from 659 the hinterland can be suggestive of three possibilities: 1 . The Cuirasse sands are sourced

660 from pre-existing recycled Meso-Cenozoic sediments from the onshore Senegal basin, 2 . The 661 size and position of the Senegal River during the Miocene to Pliocene may have been smaller and restricted to the basin interior similar to the modern-day Saloum, Gambia and Casamance rivers, 3 . If the Senegal River catchment was the same in the Miocene to Pliocene at it is today, any sediment derived from within the Mauritanides and WesternWAC may have been delivered directly offshore, beyond the continental slope through a channelised system.

Petrographic analysis of 30 samples of sediment collected from modern-day river systems and Cenozoic deposits from onshore Senegal and The Gambia record an arenitic composition, with little variation, suggestive of a cratonic source.

671 Discrimination of the tdHM assemblages demonstrates that sediments south of the Senegal

672 River are representative of a recycled sediment from the Meso-Cenozoic onshore Senegal

673 basin and whilst the tdHM is similar throughout, any subtle variations may have been lost 674 through preferential weathering and erosion. $\mathrm{U} / \mathrm{Pb}$ dating of zircons from the Casamance 675 and Gambia provinces indicate a paleo-river system which may have sourced sediment from the Leo-Man Shield which includes Archean TTG gneisses and 200 Ma CAMP basalts. 
The Senegal River contains a green-schist facies heavy mineral assemblage (amphibole, epidote, pyroxene and garnet) that indicates transport of fresh detritus from outside the

679 Senegal Basin, sourced from up to $800 \mathrm{~km}$ away which includes the denudation of the 680 western margin of the WAC and Mauritanides. U/Pb dating of zircons confirms the source 681 region of the Senegal River, transporting detritus from both the Neo-Proterozoic 682 Mauritanides and the Paleo-Proterozoic KKI. It is also possible that the Senegal River has at 683 some point in its history eroded as far south as the Leo-Man Shield, due to the occurrence 684 of Neo-Archean age zircons.

685 The variability of garnet and tourmaline species in samples from the Senegal River infers a 686 mixed metasedimentary, granitic and metasomatic source-lithology, supporting the 687 interpretation of a very large catchment region that precludes a single lithological-source. 688 The probable lithological-source regions within the WAC include: Pan African I basement 689 rocks, including granites, quartzites and staurolite/garnet grade schists of the Hercynian 690 Belt. Neoproterozoic and Palaeozoic greenschists within the Hercynian Belt, and

691 greenschists of the Paleoproterozoic KKI with associated skarn-type mineralisation. However, shifts in tourmaline species is suggestive of progressive unroofing of the Mauritanides throughout the Mesozoic to recent, exemplified by predominantly metasedimentary schorl-buergerite tourmalines of the Hercynian orogenic belt and the comparatively Mg enriched (dravitic) tourmalines from the older Pan African granites of the 696 Mauritanides.

697 Whilst the provenance of these sediments share a common source region, there have been several documented changes in climate and transitional modes of deposition throughout the Quaternary. Fluvial activity in most of North Africa's Sahel region ceased during the 
Pleistocene epoch due to the hyper-arid climate, coinciding with the last glacial maximum.

701

702

703

704

705

706

707

708

709

710

711

712

713

714

715

716

717

718

719

720

721

722

723

Hyper-aridity diminished plant-cover and reduced chemical-weathering, giving rise to optimal conditions to facilitate the generation of smectite within the high-altitude regions of the Mauritanides and western WAC. During the Holocene interglacial, the northward expansion of the ITCZ marked the beginning of the first African humid periods; renewing the west African monsoon and reactivating the fluvial systems of Senegal and Gambia. This increase in precipitation resulted in increased denudation of the Mauritanides and WesternWAC and the prevalent recycling of sediments deposited in the Meso-Cenozoic Senegal basin. The occurrence of smectite within Thiago quarry is interpreted to provide evidence for overbank flooding of the Senegal River into Lake de Guiers, providing evidence for the presence of lacustrine environments during the African humid period.

The Miocene-Pliocene Age Cuirasse sandstone from the Tivaouane Quarry reveals a period of marine transgression which demonstrates coastal recycling of basin sediments. Whilst it is possible to assume the relative position of the Senegal River during the Miocene-Pliocene was similar to the modern-day river, it is difficult to predict how big the river was. There is evidence during the Quaternary to suggest that many NW-African rivers transitioned between periods of stagnation and enhanced flow. So, the lack of heavy minerals diagnostic of renewed hinterland erosion could be due to a smaller Senegal River confined to the basin interior or fresh detritus from the Western-WAC was delivered directly offshore.

This integrated mineralogical study of Cenozoic sediments has established two distinct provenance groups; 1. prevalent recycling of Senegal basin-sediments by the Ferlo, Saloum, Gambia and Casamance Rivers which may have at least in part been derived from the LeoMan Shield and the WAC, and 2. continued erosion and recycling of hinterland-sediments via the modern-day Senegal River. 
724 Supplementary Data

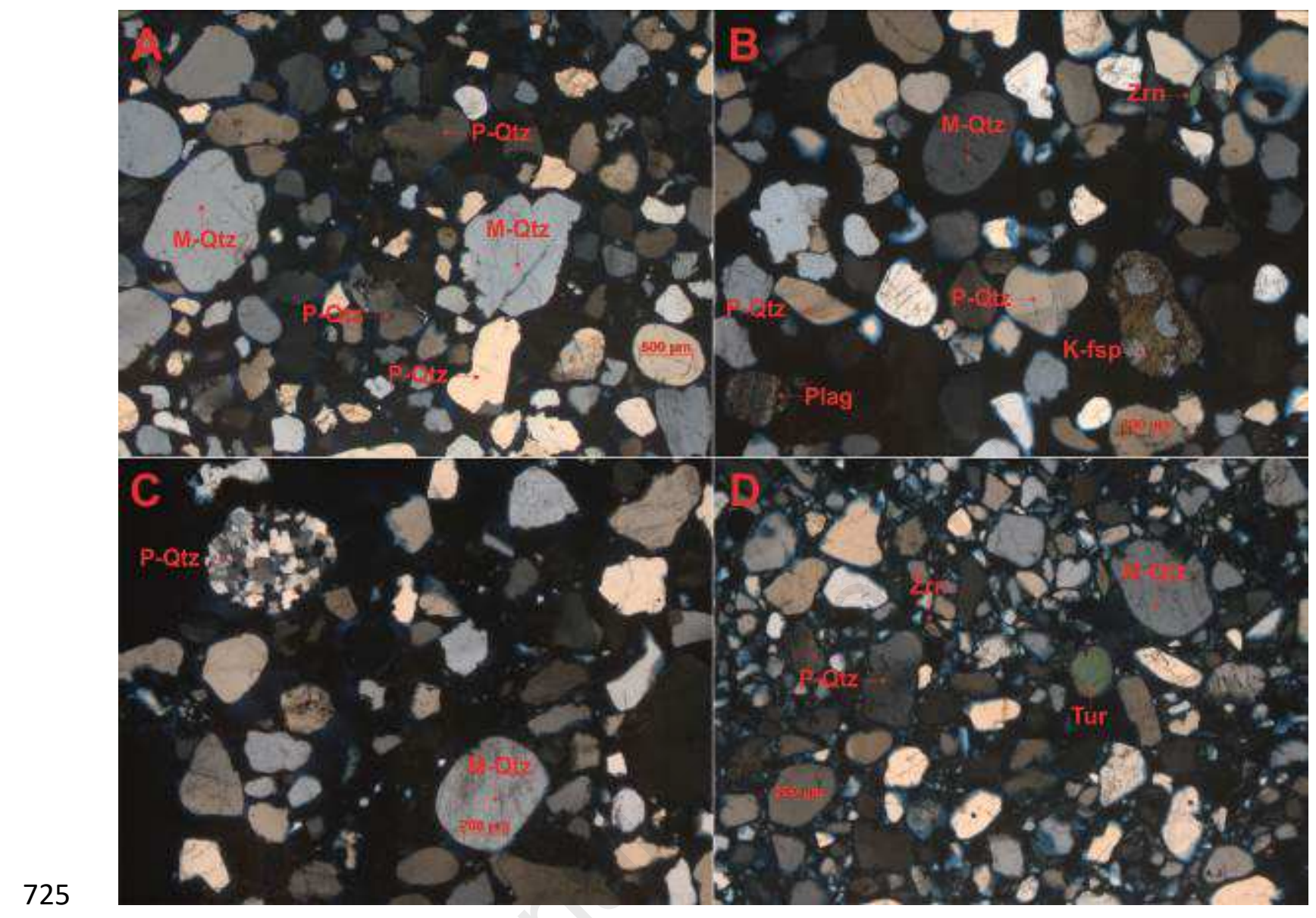

726 Figure S 1, Cross-polarised thin-section photomicrographs: P-Qtz=Polycrystalline quartz, M-Qtz=Monocrystalline quartz,

Plag=Plagioclase feldspar, $K$-fsp=Potassium feldspar. Tur=Tourmaline and Zrn=Zircon. A, Sample 618, orange/brown sand from Dalaba pit, Gambia. B, Sample 630, brown sand from the River Senegal. C, Sample 637, grey sand from Thiago quarry. $D$, Sample 640, brown sand from Tivaouane quarry. 


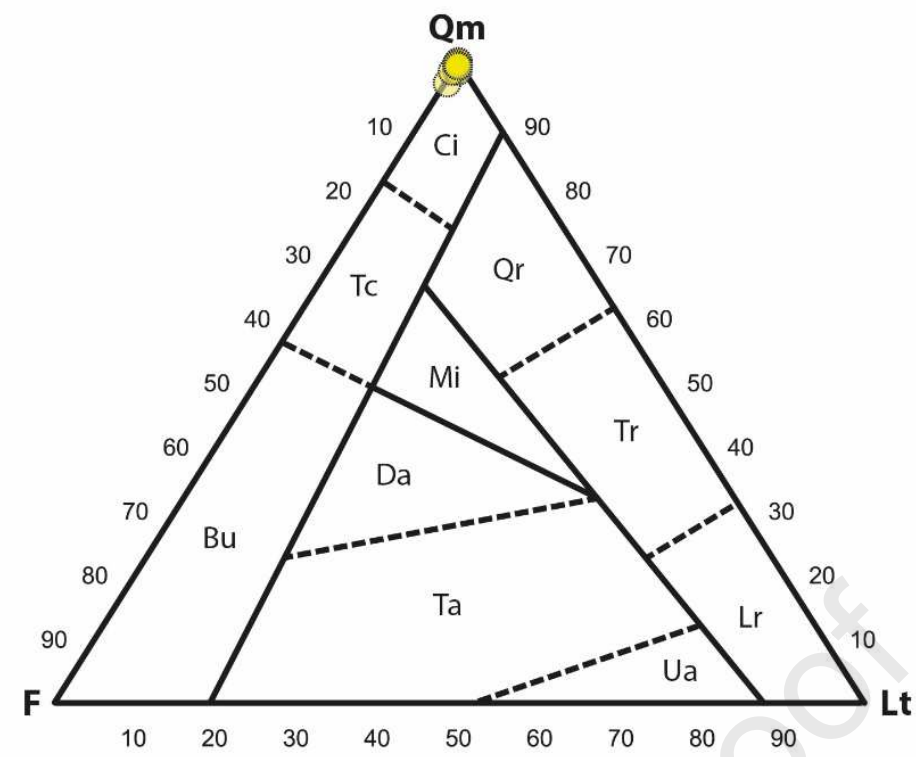

Figure S 2 Qm-F-Lt plots for classification of all modern-day sands and sandstones, displaying the potential subdivisions according to the inferred provenance type, (modified from Dickinson et al., 1983). Qm=Quartz-monocrystalline, F=feldspar, Lt=Total lithic grains. $\mathrm{Ci}=$ Craton interior, Tc=Transitional continental, Bu=Basement uplift, Mi=Mixed, Da=Dissected arc, Ta=Transitional arc, Ua=Undissected arc, Qr=Quartzose recycled, $\mathrm{Tr}=\mathrm{Transitional}$ recycled and $\mathrm{Lr}=\mathrm{Lithic}$ recycled.

\section{Acknowledgements}

736 This study is part of the lead authors PhD project at the University of Manchester. We thank the sponsoring companies of NARG for their continued financial and scientific support.

Special thanks to University of Dakar, Earth Institute for logistical support, and to 
741

742

743

744

745

746

747

748

749

750

751

752

753

754

755

756

757

758

759

760

761

762

763

764

765

766

767

768

References

Adam, O., Schneider, T., Enzel, Y., Quade, J., 2019. Both differential and equatorial heating contributed to African monsoon variations during the mid-Holocene. Earth and Planetary Science Letters. 522, 20-29.

Ali, S., Stattegger, K., Garbe-Schönberg, D., Kuhnt, W., Kluth, O., Jabour, H., 2014. Petrography and geochemistry of Cretaceous to Quaternary siliciclastic rocks in the Tarfaya basin, SW Morocco: implications for tectonic setting, weathering, and provenance. Internanational Journal of Earth Sciences. 103, 265-280. DOI 10.1007/s00531-013-0965-6.

Arantegui, A.I., 2018. Characterisation of Mesozoic Depositional Systems along the Atlantic Passive Margin of Morocco. North Aaiun-Tarfaya Basin. A thesis submitted to the University of Manchester for the degree of Doctor of Philosophy in the Faculty of Science and Engineering, 1-172.

Armitage, S.J., Bristow, C.S., Drake, N.A., 2015. West African monsoon dynamics inferred from abrupt fluctuations of Lake Mega-Chad. Proceedings of the National Academy of Sciences of the United States of America. 112 (28) 8543-8548. https://doi.org/10.1073/PNAS.1417655112

Aubrecht, R., Méres, S., Sýkora, M., Mikuš, T., 2009. Provenance of the detrital garnets and spinels from the Albian sediments of the Czorsztyn Unit (Pieniny Klippen Belt, Western Carpathians, Slovakia) Geologica Carpathica. 60, 463-483.

Bateman, R.M., Catt, J.A. 2007., Provenance and palaeoenvironmental interpretation of superficial deposits, with particular reference to post-depositional modification of heavy mineral assemblages. Developments in Sedimentology. 58, 151-188.

Becker, J. J., Sandwell, D. T., Smith, W.H.F., Braud, J., Binder, B., Depner, J., Fabre, D., Factor, J., Ingalls, S., Kim, S-H., Ladner, R., Marks, K., Nelson, S., Pharaoh, A., Trimmer, R., Von Rosenberg, J., Wallace, G., Weatherall, P., 2009. Global Bathymetry and Elevation Data at 30 Arc Seconds Resolution: SRTM30_PLUS, Marine Geodesy, 32:4, 355-371.

Beghina, J., Guilbaud, R., Poulton, S.W., Gueneli, N., Brocks, J.J., Storme, J-Y., Blanpied, C., Javaux, E.J., 2017. A palaeoecological model for the late Mesoproterozoic-early 
769

770

771

772

773

774

775

776

777

778

779

780

781

782

783

784

785

786

787

788

789

790

791

792

793

794

795

Neoproterozoic Atar/El Mreïti Group, Taoudeni Basin, Mauritania, northwestern Africa. Precambrian Research 299, 1-14.

Bellion, Y., Crevola, G., 1991. Cretaceous and Cainozoic magmatism of the Senegal Basin (West Africa): a review. In Magmatism in extensional structural settings, 189-208.

Binks, M., Fairhead, J.D., 1992. A plate tectonic setting for the Mesozoic rifts of West and Central Africa. Tectonophysics. 213, 141-151.

Biscaye, P., 1965. Mineralogy and sedimentation of recent deep-sea clay in the Atlantic Ocean and adjacent seas and oceans. GSA Bulletin. 76 (7), 803-832.

Boudzoumou, F., Vandammeb, D., Affaton, P., Gattacceca, J., 2011. Neoproterozoic paleomagnetic poles in the Taoudeni basin (West Africa). Geoscience 343, 284-294.

Brownfield, M.E., Charpentier, R.R., 2003. Assessment of the undiscovered oil and gas of the Senegal Province, Mauritania, Senegal, The Gambia, and Guinea-Bissau, Northwest Africa. U.S. Geological Survey Bulletin 2207-A, 1-27.

Brownfield, M.E., 2016. Assessment of undiscovered oil and gas resources of the Senegal Province, northwest Africa, in Brownfield, M.E., compiler, Geologic assessment of undiscovered hydrocarbon resources of Sub-Saharan Africa: U.S. Geological Survey Digital Data Series 69-GG, chap. 2, 1-20p. http://dx.doi.org/10.3133/ds69GG.

Burke, K., 1976. Development of graben associated with the initial ruptures of the Atlantic Ocean. Tectonophysics. 36, 93-112.

Chamley, H., Debrabant, P., Flicoteaux, R. 1988. Comparative evolution of the Senegal and eastern central Atlantic Basins, from mineralogical and geochemical investigations. Sedimentology. 35, 85-103.

Collier, N.C. et al., 2019. Gaseous carbonation of cementitious backfill for geological disposal of radioactive waste: Nirex Reference Vault Backfill. Applied Geochemistry. 106. pp. 120133. ISSN 0883-2927

Coutros, P.R., 2018. A Fluid past: Socio-hydrological systems of the West African Sahel across the long durée. WIREs Water. 6:e1365, 1-22. https://doi.org/10.1002/wat2.1365 
Culver, S.J., Hunt, D., 1991. Lithostratigraphy of the Precambrian-Cambrian boundary sequence in the southwestern Taoudeni Basin, West Africa. Journal of African Earth Sciences (and the Middle East). 13, 407-413.

799

Davison, I., 2005. Central Atlantic margin basins of North West Africa: Geology and

800 hydrocarbon potential (Morocco to Guinea). Journal of African Earth Sciences 43, 254-274.

801 Debenay, J.P., Pages, J., Guillou, J.J. 1994. Transformation of a subtropical river into a 802 hyperhaline estuary: the Casamance River (Senegal) paleogeographical implications. 803 Palaeogeography, Palaeoclimatology, Palaeoecology. 107, 103-119.

804 Dia, O., 1984. La chaı̂ne panafricaine et hercynienne des Mauritanides face au bassin 805 Proterozoıque superieur a`Devonien de Taoudenni, dans le secteur clef de Mejeria 806 (Taganet, sud RIM). These d'Etat, Universite' Aix-Marseille III, Marseille, 1-516.

807 Dickinson, W.R., Beard, L.S., Brakenridge, G.R., Ferguson, R.C., Inman, K.F., Knepp, P.A., 808 Lindberg, F.A., Ryberg, P.T., 1983. Provenance of North American Phanerozoic sandstones in 809 relation to tectonic setting. Geological Society of American Bulletin. 94, 222-235.

810 Ehrmann, W., Schmiedl, G., Beuscher, S., KruÈger, S., 2017. Intensity of African Humid 811 Periods Estimated from Saharan Dust Fluxes. PLoS ONE. 12 (1), 1-18: e0170989. 812 doi:10.1371/journal.pone.0170989.

813 Farrant, A.R., et al., 2018. Gone with the wind: Dune provenance and sediment recycling in 814 the northern Rub' al-Khali, United Arab Emirates, Arabia. Journal of the Geological 815 Society $176,(2)$ 269-283.

816 Faye, S., Maloszewski, P., Stichler, W., Trimborn, P., Cisse, S., Faye, C., Gaye, B., 2004.

817 Groundwater salinization in the Saloum (Senegal) delta aquifer: minor elements and isotopic 818 indicators. Science of the Total Environment. 343, 243-259.

819 Flicoteaux, R., 1982. Genèse des phosphates alumineux du Sénégal occidental. Étapes et 820 guides de l'altération. Strasbourg: Institut de Géologie - Université Louis-Pasteur. Sciences 821 Géologiques. Mémoire, 67, 1-229. 
822

823

824

825

826

827

828

829

830

831

832

833

834

835

836

837 Grimaud, J-L., Rouby, D., Chardon, D., Beauvais, A., 2018 Cenozoic sediment budget of West 838

839

840

841

842

843 Guiraud, R., Bosworth, W., Thierry, J., Delplanque, A., 2005. Phanerozoic geological

844 evolution of Northern and Central Africa: An overview. Journal of African Earth Sciences. 43, 845

846 Gunn, A.G., Dorbor, J.K., Mankelow, J.M., Lusty, P.A.J., Deady, E.A., Shaw, R.A., Goodenough,

847 K.M., 2018. A review of the minimal potential of Liberia. Ore Geology Reviews. 101, 413848

Fossum, K., Morton, A.C., Dypvik, H. and Hudson, W.E., 2019. Integrated heavy mineral study of Jurassic to Paleogene sandstones in the Mandawa Basin, Tanzania: Sediment provenance and source-to-sink relations. Journal of African Earth Sciences. 150, 546-565.

Garzanti, E., 2017. The maturity myth in sedimentology and provenance analysis. Journal of Sedimentary Research. 87, 353-365.

Garzanti, E., Andò, S., 2019. Heavy minerals for junior woodchucks. Minerals. 9(3):148, 1-25. DOI: $10.3390 / \min 9030148$.

GEM., 2020. Geognostics Earth Model.

Gladimi, S., 1977. Présentée pour obtenir le titre de Docteur de 3ème cycle en Géologie Appliquée PhD Thesis Universite Cheikh Anta Diop "de Dakar Facilté des Sciences et Techniques' Département de Géologie, 1-116.

Gerson, J.R., Driscoll, C.T., Hsu-Kim, H. and Bernhardt, E.S., 2018. Senegalese artisanal gold mining leads to elevated total mercury and methylmercury concentrations in soils, sediments, and rivers. Elementa Science of the Anthropocene, 6: 11, 1-14. DOI: https://doi.org/10.1525/elementa.274.

Africa and the Niger delta. Basin Research 30, 169-186.

Gueye, M., Siegesmund, S., Wemmer, K., Pawlig, S., Drobe, M., Nolte, N., Layer, P., 2007. New evidences for an early Birimian evolution in the West African Craton: An example from the Kédougou-Kénieba inlier, southeast Senegal. South African Journal of Geology. 110, 511534. 83-143. 431. 
849

850

851

852

853

854

855

856

857

858

859

860

861

862

863

864

865

866

867

868

869

870

871

872

873

874

875

Hamerlynck O., Duvail S., 2003. La restauration du delta du fleuve Sénégal en Mauritanie. Une application de l'approche écosystémique. http://app.iucn.org. viii, 87p

Hansen. D.M., Redfern, J., Federici, F., di-Biase, D., Bertozzi, G., 2008. Miocene igneous activity in the northern sub-basin, offshore Senegal, NW Africa. Marine and Petroleum Geology. 25, 1-15.

Hathon, E., 2018. The SNE Discovery Offshore Senegal-Moving a Frontier Basin to Emergent. In 80th EAGE Conference and Exhibition 2018. European Association of Geoscientists \& Engineers. Vol. 2018, No. 1, pp. 1-5.

Henry, D.J. and Guidotti, C.V. 1985. Tourmaline as a petrogenetic indicator mineral: an example from the staurolite-grade metapelites of NW Maine. American Mineralogist, 70, 115.

Ingersoll, R.V., Bullard, T.F., Ford, R.L., Grimm, J.P., Pickle, J.D., Sares, S.W., 1984. The effect of grain size on detrital modes: a test of the Gazzi-Dickinson point-counting method Journal of Sediment Petrology. 54, 103-116.

Isupova, M.V., Mikhailov, V.N., 2008. Hydrological and Morphological Processes in Senegal River Mouth Area. Water Resources. 35, No. 1. 30-42.

Kattan, Z., Gac, J.Y., Probst, J.L., 1987. Suspended sediment load and mechanical erosion in the Senegal basin - estimation of the surface runoff concentration and relative contributions of channel and slope erosion. Journal of Hydrology. 92, 59-76.

Kemp, S.J., Ellis, M.A., Mounteney, I., Kender, S., 2016a. Palaeoclimatic implications of highresolution clay mineral assemblages preceding and across the onset of the PalaeoceneEocene Thermal Maximum, North Sea Basin. Clay Minerals. 51, 793-813.

Kemp, S.J., Smith, F.W., Wagner, D., Mounteney, I., Bell, C.P., Milne, C.J., Gowing, C.J.B., Pottas, T.L., 2016b. An Improved Approach to Characterize Potash-Bearing Evaporite Deposits, Evidenced in North Yorkshire, United Kingdom. Economic Geology. 111, 719-742.

Labails, C., Olivet, J.L., Aslanian, D., Roest, W.R., 2010. An alternative early opening scenario for the Central Atlantic Ocean. Earth and Planetary Science Letters. 297, 355-368. 
876 Ledru, P., Pons, J., Milési, J.P., Feybesse, J.L., Johan, V., 1991. Transcurrent tectonics and

877 polycyclic evolution in the Lower Proterozoic of Senegal-Mali. Precambrian Research. 50, 878 337-354.

879 Lehner, P., De Ruiter, P.A.C., 1977. Structural history of Atlantic margin of Africa. The 880 American Association of Petroleum Geologists Bulletin. Volume 61, Number 7, 961-981.

881 Li, Z-H., Qu, H-J., Gong, W-B., 2015. Late Mesozoic basin development and tectonic setting 882 of the northern North China Craton. Journal of Asian Earth Sciences. 114, 115-139.

883 Lézine, A-M., Casanova, J., Hillaire-Marcel, C., 1990. Across an early Holocene humid phase 884 in western Sahara: Pollen and isotope stratigraphy. Geology. 18 (3), 264-267.

885 Mange, M.A., Maurer H.F.W., 1992. Heavy Minerals in Colour. (Chapman and Hall).

886 Mange, M.A., Morton, A.C., 2007. Geochemistry of heavy minerals. Developments in 887 Sedimentology. 58, 345-391.

888 Markwitz, V., Kim, A.A.H., Miller, J., 2015. Compilation of West African mineral deposits: 889 Spatial distribution and mineral endowment. Precambrian Research. 274, 61-81.

890 McIntosh, R. J., McIntosh, S. K., Bocoum, H., 2016. The search for Takrur: Archaeological 891 excavations and reconnaissance along the middle Senegal Valley. Journal of African 892 Archaeology. 15 (2), 260-261.

893 McKinley, J.M., Worden, R.M., Ruffell, A.H., 2003. Smectite in sandstones: a review of the controls on occurrence and behaviour during diagenesis. International Association of Sedimentologists. 34, 109-128.

896 Michel, P., 1973. Les bassins des fleuves Senegal et Gambie. Etude geomorphologique. Memoires ORSTOM, No. 63, Paris, 1-810.

898 Milési, J.P., Ledru, P., Feybesse, J.L., Dommanget, A., Marcoux, E., 1992. Early Proterozoic ores deposits and tectonics of the Birimian orogenic belt. West Africa. Precambrian Research. 58, 305-344.

901 Miller, G., Kominz, M.A., Browning, J.V., Wright, J.D., Mountain, G.S., Katz, M.E., Sugarman, 902 P.J., Cramer, B.S., Christie-blick, N., Pekar, S.F., 2005. The Phanerozoic Record of Global Sea903 Level Change. 1293-1298. DOI: 10.1126/science.1116412. 
904

905

906

907

908

909

910

911

912

913

914

915

916

917

918

919

920

921

922

923

924

925

926

927

928

929

930

Morton, A.C., 1984. Stability of detrital heavy minerals in Tertiary sandstones from the North Sea Basin. Clay Minerals. 19, 287-308.

Morton, A.C., Hallsworth, C., 1994. Identifying provenance-specific features of detrital heavy mineral assemblages in sandstones. Sedimentary Geology. 90, 241-256.

Morton, A.C., Hallsworth, C.R., 1999. Processes controlling the composition of heavy mineral assemblages in sandstones. Sedimentary Geology. 124 (1), 3-29.

Morton, A.C., Hounslow, M.W., Frei, D., 2013. Heavy-mineral, mineral-chemical and zirconage constraints on the provenance of Triassic sandstones from the Devon coast, southern Britain. Geologos. 19, 1-2: 67-85.

Mounteney, I., Burton, A.K., Farrant, A.R., Watts, M.J., Kemp, S.J., Cook, J.M., 2017. Heavy mineral analysis by ICP-AES a tool to aid sediment provenancing. Journal of Geochemical Exploration. 184, 1-10.

Mourlot, Y., Calvès, G., Clift, P.D., Baby, G., Chaboureau, A.C., Raisson, F., 2018. Seismic stratigraphy of Cretaceous eastern Central Atlantic Ocean: Basin evolution and palaeoceanographic implications. Earth and Planetary Science Letters. 499, 107-121.

Nahon, D., Janot, C., Karpoff, A.M., Paquet, H., Tardy, Y., 1977. Mineralogy, petrography and structures of iron crusts (ferricretes) developed on sandstones in the western part of Senegal. Geoderma. 19. 263-277.

Ndiaye, A., Diouf, B., Diara, M., Giresse, P., 2016a. Clay Fraction Distribution in the Sediments of the Senegal River Estuary after the Diama (Senegal) Dam Construction. Journal of Shipping and Ocean Engineering, David Publishing. 35-45.

Ndiaye, M., Ngom, P.M, Gorin, G., Villeneuve, M., Sartori, M., Medou, J., 2016b. A new interpretation of the deep-part of Senegal-Mauritanian Basin in the Diourbel-Thies area by integrating seismic, magnetic, gravimetric and borehole data: Implication for petroleum exploration. Journal of African Earth sciences. 121, 330-341.

Nicholson, S.E., 2017. The ITCZ and the seasonal cycle over equatorial Africa. American Meteorological Society, 337-348. DOI:10.1175/BAMS-D-16-0287.1. 
931

932

933

934

935

936

937

938

939

940

941

942

943

944

945

946

947

948

949

950

951

952

953

954

955

956

957

958

Okay, N., Ergu, B., 2005. Source of the basinal sediments in the Marmara Sea investigated using heavy minerals in the modern beach sands. Marine Geology. 216, 1-15.

Pacini, N., Harper, D.M., 2016. Ecohydrological analysis of tropical river basin development schemes in Africa. Ecohydrology: Processes, Models and Case Studies. Chapter 12, 223-246.

Page, A., 1988. Rock deformation associated with the displacement of allochthonous units in the central segment of the Caledono-Hercynian Mauritanide belt (Islamic Republic of Mauritania and eastern Senegal) Journal of African Earth Sciences. 7, No. 1, 265-283.

Pages, A., Citeau, J., 1990. Rainfall and salinity of a Sahelian estuary between 1927 and 1987. Journal of Hydrology, 113, 325-341.

Pan, B., Pang, H., Gao, H., Garzanti, E., Zou, Y., Liu, X., Li, F., Jia, Y., 2016. Heavy-mineral analysis and provenance of Yellow River sediments around the China Loess Plateau. Journal of Asian Earth Sciences. 127, 1-11.

Pascal, M., Sustrac, G., 2005. Phosphate Deposits of the World: Volume 2, Phosphate Rock Resources. Chapter 37. ISBN 052167333X, 9780521673334.

Paton, C., Hellstrom, J., Paul, B., Woodhead, J., Hergy J., 2011. Iolite: Freeware for the visualisation and processing of mass spectrometric data. Journal of Analytical Spectrometry. $26,2508-2518$.

Pawlig, S., Gueye, M., Klischies, R., Schwarz, S., Wemmer, K., Siegesmund, S., 2006. Geochemical and Sr-Nd isotopic data on the Birimian of the Kedougou-Kenieba Inlier (Eastern Senegal): Implications on the Palaeoproterozoic evolution of the West African Craton. South African Journal of Geology. 109(3):411-427

Ponsard, J. F., Roussel, J., Villeneuve, M., 1988. The Pan-African orogenic belt of southern Mauritanides and northern Rokelides (southern Senegal and Guinea, West Africa): gravity evidence for a collisional suture. Journal of African Earth Sciences. 7, No. 2. 463-472.

Ritz, M., Bellion, Y., 1988. Geologic sections across the onshore Senegal-Mauritania basin derived from geoelectric studies. Journal of Earth Sciences. 26, 65-73.

Ritz, M., Bellion, Y., 1994. An audiomagnetotelluric study of the Leona Batholith, Senegal. Journal of Applied Geophysics. 32, 117-123. 
959

960

961

962

963

964

965

966

967

968

969

970

971

972

973

974

975

976

977

978

979

980

981

982

983

984

985

Roger, J., et al., 2009. Notice explicative de la cartographie multi-couches à $1 / 50000$ et 1/20 000 de la zone d'activité du Cap-Vert (Sénégal), 1-245.

Rollinson, H., 2016. Archaean crustal evolution in West Africa: A new synthesis of the Archaean geology in Sierra Leone, Liberia, Guinea and Ivory Coast. Precambrian Research. 281:1, 1-25.

Shahin, M., 2002. Hydrology and Water Resources of Africa. ISBN 978-0-306-48065-2

Shahjahan, M., 1970. Factors controlling the geometry of fluvial meanders. Hydrological Sciences Journal, 15:3, 13-24, DOI: 10.1080/02626667009493968.

Simier, M., Laurent, C., Ecoutin, J-M., Albaret, J-J., 2006. The Gambia River estuary: A reference point for estuarine fish assemblages studies in West Africa. Estuarine, Coastal and Shelf Science. 69, 615-628.

Stanzel, P., Kling, H., Bauer, H., 2018. Climate change impact on West African rivers under an ensemble of CORDEX climate projections. Climate Services. 11, 36-48.

Storetvedt, K. M., 1985. The pre-drift central Atlantic; A model based on tectonomagmatic and sedimentological evidence. Journal of Geodynamics 2, 275-290.

Trenous, P-Y., Michel, P., 1971. Etude de la structure du dome de Guier (Senegal nordoccidental). Bulletin de la Societe Geologique de France. (1-2), 133-139.

Uchupi, E., 1989. The tectonic style of the Atlantic Mesozoic rift system. Journal of African Earth Sciences. 8. Nos. 2/3/4, 143-164.

Van-Loon, A.J., Mange, M.A., 2007. 'In situ' dissolution of heavy minerals through extreme weathering, and the application of the surviving assemblages and their dissolution characteristics to correlation of Dutch and German silver sands. Developments in Sedimentology. 58, 189-213.

Van Zinderen-Bakker, E.M., Maley J., 1977. Late Quaternary palaeoenvironments of the Saharan region. Palaeoecology of Africa and the Surrounding Islands, Vol 11, 83-104.

Vermeesch, P., 2018. IsoplotR: A free and open toolbox for geochronology. Geoscience Frontiers. 9, 1479-1493. 
986

987

988

989

990

991

992

993

994

995

996

997

998

999

1000

1001

1002

1003

1004

1005

1006

1007

Villeneuve, M., 2008. Review of the orogenic belts on the western side of the West African craton: the Bassarides, Rokelides and Mauritanides. The Boundaries of the West African Craton. Geological Society, London, Special Publications, 297, 169-201.

Villeneuve, M., Fournier, F., Cirilli, S., Spina, A., Ndiaye, M., Zamba, J., Viseur, S., Borgomano, J., Ngom, P.M., 2015. Structure of the Paleozoic basement in the Senegalo-Mauritanian basin (West Africa). Bulletin de la Societe Geologique de France. 186, 2-3.

Whalen, L., Gazel, E., Vidito, C., Puffer, J., Bizimis, M., Henika, W., Caddick, M.J., 2015. Supercontinental inheritance and its influence on supercontinental breakup: The Central Atlantic Magmatic Province and the breakup of Pangea. Geochemistry, Geophysics, Geosystems. 16, 3532-3554. doi:10.1002/2015GC005885.

Wright, W.I., 1938. The composition and occurrence of garnets. American Mineralogist. 23, 436-449.

Yavuz, F., Karakaya, N., Yıldırım, D.K., Karakaya, M.C., Kumral, M., 2014. A Windows program for calculation and classification of tourmaline-supergroup. Computers \& Geosciences. 63, 70-87.

Ye, J., Chardon, D., Rouby, D., Guillocheau, F., Dall'asta, M., Ferry, J-N., Broucke, O., 2017. Paleogeographic and structural evolution of north-western Africa and its Atlantic margins since the early Mesozoic. Geosphere, V13, no. 4. 1254-1284, doi:10.1130/GES01426.1.

Youbi, N., Ernst, R., Söderlund, U., Bertrand, H., Doblas, M., El Hachimi, H., Kouyaté, D., Soulaimani, A., Hafid, A., Ikenne, M., Chaham, K.R., 2011. Large igneous provinces of the West African Craton: The record preserved in regional dyke swarms. International Association of Volcanology and Chemistry of the Earth's Interior, 1-12. 


\section{Highlights}

- An integrated mineralogical provenance study of Cenozoic and modern-day sediments from Senegal.

- Modern-day Senegal River erosional catchment includes the Mauritanides, western West African Craton, Kédougou-Kéniéba Inlier.

- The Ferlo, Saloum, Gambia and Casamance rivers are currently recycling Meso-Cenozoic sediments from within the onshore Senegal basin.

- $\mathrm{U} / \mathrm{Pb}$ dating of detrital zircons suggests Senegalese paleo-river systems may have eroded into the Leo-Man Shield. 


\section{Declaration of interests}

$\bigotimes$ The authors declare that they have no known competing financial interests or personal relationships that could have appeared to influence the work reported in this paper.

$\square$ The authors declare the following financial interests/personal relationships which may be considered as potential competing interests: 